„Logopedia Silesiana”, t. 9, ISSN 2391-4297

https://doi.org/10.31261/LOGOPEDIASILESIANA.2020.09.08

pp. 1-18: English language version; pp. 19-35: Polish language version

(c) BY-SA

\title{
Ewa Dzį̨CiOŁ-Chlibiuk
}

Institute of Linguistics and Literature, Faculty of Humanities, University of Natural Sciences and Humanities in Siedlce

(D) https://orcid.org/0000-0001-7034-0631

\section{Storytelling superstructure in the utterances of hearing impaired people}

\begin{abstract}
AвSTRACT: Storytelling, the most common form of shaping both linguistic and cultural texts, is the most frequently repeated pattern in interpersonal communication. The article dwells on the characteristics of this narrative expression, paying particular attention to its specific structure. Further on, the author provides a short description on how the narrative competence has been developing. The article includes the author's own research designed and performed to elicit challenges hearingimpaired people face when creating a written narrative text (story) based on a picture story, and to find an answer to the question on whether, in the mind of a hearing-impaired person, the storytelling structure exists. Finally, the author deduces that it seems reasonable, on the basis of the collected material, to assume that the integrated education as well as speech therapy of hearing-impaired people should include exercises shaping the ability to create stories as mastering this skill is connected with the level of linguistic and communicative competence.
\end{abstract}

KEY wORDS: storytelling superstructure, hearing-impaired people, narrative competence

\section{Superstruktura opowiadania na podstawie wypowiedzi osób z uszkodzeniami słuchu}

STRESZCZENIE: Opowiadanie jest najpowszechniejszą formą kształtowania tekstów, nie tylko językowych, lecz także tekstów kultury. Jest najczęściej powielanym schematem konstruowania wypowiedzi w komunikacji międzyludzkiej. W artykule omówiono charakterystyczne cechy tej formy wypowiedzi narracyjnej, zwracając szczególną uwagę na jej strukturę. Podano krótki opis kształtowania się kompetencji narracyjnej. Przedstawiono wyniki badań własnych, których celem było sprawdzenie, jakie trudności sprawia osobom z wadą słuchu tworzenie tekstu narracyjnego (opowiadania) na podstawie historyjki obrazkowej, w formie pisanej. A przede wszystkim - czy w umysłach osób z uszkodzonym słuchem istnieje struktura opowiadania. Na podstawie zebranego materiału zasadne wydaje się założenie, że w kształceniu osób z niepełnosprawnością słuchową, jak także w programowaniu terapii logopedycznej, należy uwzględnić ćwiczenia z zakresu kształtowania sprawności budowania opowiadań. Opanowanie tej umiejętności świadczy o poziomie kompetencji językowej i komunikacyjnej.

SŁOWA KLUCZOWE: superstruktura opowiadania, osoby z uszkodzonym słuchem, kompetencja narracyjna 
The level of language acquisition and its set of rules condition sound engagement in different communicative and cultural transmissions. This inherent element of gaining knowledge makes conceptualisation, structuring, and interpretation of reality possible, with regard to its categorisation and value (Cieszyńska, 2013, p. 164). The degree of linguistic development and the image of reality created in the human mind depend on mastering this narrative efficiency (Grabias, 2015, p. 22). Therefore, by analysing narrative forms (description and story) it is possible to establish how an examined person perceives reality. According to the assumptions of cognitive linguistics and sociolinguistics, one can notice differences, normative / non-normative originality in the perception of the world and its segmentation by analysing narrative texts and the elements of the linguistic structure and its means (Dzięciol-Chlibiuk, 2019, p. 218). Narrative forms are texts that enable the assessment of all language subsystems, language and communication competences and skills, as well as individual ways to conceptualise knowledge of the world (Grabias, 2012, p. 62, 64). Story (the ability to time sequence events) and description ${ }^{1}$ (the ability to perceive phenomena in spatial relations) manifest different structure and composition; hence, for diagnostic purposes, they are differentiated (Grabias, 2015, p. 22).

\section{Storytelling - one of the basic forms of narrative}

The most common form of shaping both linguistic and cultural texts, storytelling is the most frequently repeated pattern in interpersonal communication. Katarzyna Wyrwas notices that this form allows one to reflect on time laps and chronology, the two factors one refers to in order to organise chaotic reality (events, own experiences) and introduce an order to understand both themselves and the world (Wyrwas, 2014, p. 13).

Literary theory defines a story as an account of past events. This concept has been analysed by a substantial number of scholars and researchers. Kulawik (1997, p. 328) speaks about a narrative element that captures a sequence of events of a causal relation - the plot, while Nagajowa (1990, p. 138) calls a story a chronological and cause-effect correlation of events, and similarly, Jan Kulpa and Ryszard Więckowski (1997, p. 62), define a story as an occurrence, a course of actions and

${ }^{1}$ In my previous article, I have discussed the characteristic features of description as one of the forms of narrative utterance. I also presented the results of my own research on the implementation of the description structure based on the spoken and written statements of hearing impaired students see: Dzięcioł-Chlibiuk, E. (2019). Implementation of the description structure based on oral and written statements of hearing impaired people. Logopedia Silesiana, 8, pp. 209-232. 
events maintaining the relation of sequences and chronology. Additionally, some academics present a narrative as a composition of macro- and microstructures, embedding, in the case of macrostructure, exposition, complication and resolution (William Labov and Joshua Waletzky's in: Bokus, 1991, p. 16); in case of the micro one, the narrative combines the components of a plot, i.e. protagonists, supporting characters, as well as the circumstances of events (Kowal, 2006 in Kyrc, 2018, p. 86).

It is often claimed that the content of a story should be contained within a three-part introduction - body - conclusion unity organised by the subsequent emergence of events and facts (Węglińska, 1997, p. 13). The introductory element of a narrative does not have to be extensive; it can consist of a single statement presenting general information about the events, and specifying the temporal and spatial frame. The body, i.e. reporting the events, includes a detailed description of their course, outcomes, and possible consequences. This part of the story should be presented with a picturesque, vivid language. The conclusion does not have to be very complex in terms of syntax, but it should constitute a clear, unambiguous, and legible ending of the presented action. It may contain a request, or general moral message, which would summarise the events (Malendowicz, 1997, pp. 60-61).

According to Maria Nagajowa (1977), the story is rooted in an imaginative emotion-based thinking (feeling, experiencing and evaluating); thus, its syntactic structure is dominated by extended simple and compound time-casual clauses, responding to the narrative features depicting the time sequence and linking events into cause and effect chains (Nagajowa, 1977, p. 143). Ewa Wolańska (2010), however, states that the chronological and cause-effect order of a story is generally maintained by two types of inter-sentence conjunctions: (i) time sequence conjunction, i.e. adverbs, adverbial pronouns, and prepositional phrases (e.g. najpierw, po chwili, początkowo [eng.: first, after a while, initially]); and (ii) the cause-effect conjunctions, which include conjunctive expressions (e.g. dlatego też... [eng.: therefore...]) and developed groups of words (e.g. w wyniku...[eng.: as a result of ...]) (Wolańska, 2010, p. 110).

A narrative recognises a dynamic flow of events. Hence, the arcs are presented with adequate linguistic means, such as adverbs and prepositional phrases, depicting the spatial relations (e.g. potem, najpierw, wnet, zanim, wreszcie [eng.: then, first, soon, before, finally]). The storytelling employs verbs in the past form and organises events in a chronological order, logically succeeding the causeeffect correlated facts, conventional linking phrases (e.g. następnie, potem, przedtem [eng.: next, after, before]) (Witosz, 1997, pp. 23-24; Węglińska, 1997, p. 11), apt vocabulary, incl. defining the manner of the activity performed (e.g. szybko, trafnie, $z$ trudem, zabawnie, energicznie [eng.: quickly, accurately, with difficulty, fun, vigorously]), defining the protagonists, their attitudes and outlining time (e.g. w czasie wakacji [eng.: during the holidays]) and place of events (na piasz- 
czystej plaży [eng.: on a sandy beach]) (Jóźwicki, 1984, p. 23; Dereń, 2005, p. 147).

Naturally, a story is designed for different purposes; thus, the types may vary and be of informative (providing the reader with additional explanation of character's condition and behaviour), illustrating (supporting enactment and authenticating the story), or underlying nature (reporting past events, account of actions commenced in the past but completed at present, eliminating the distance between the actual time of events and the time they are being told) (Kulawik, 1997, pp. 328-329).

In terms of schooling system, a narrative is taught to combine the following types: imitative (re-telling heard or read events, based on a book, film, or theatre play); creative (made up narratives using acquired information about a literary character, based on the narrator's experiences, referring to, e.g. witnessed events); creative and imitative using dialogues (Dereń, 2005, p. 147; Nagajowa, 1990, p. 131).

More importantly, however, developing a narrative based on a picture story requires appropriate procedures (Grabias, 2012, p. 62-63; Grabias, Kurkowski \& Woźniak, 2002, p. 10, 27):

- identifying the situation that outlines a picture story; i.e. notions to which the story relates: people, animals, natural phenomena;

- establishing the storyline: arranging, naturally if possible, the situations into a logical sequence, determined by the causes-effects system;

- inscribing the storyline into the developing structure, i.e. superstructure (orientation, exposition, complication, resolution, coda);

- developing mental layout (psychological features of the protagonist) - a speaker fluent in narrative techniques has the ability to revive characters by equipping them with psychological traits (movement, emotions, activities, states);

- defining the position of the narrator - the storyteller may have the ability to naturally overtake the role of the narrator (the person managing the story's action);

- applying apt language - assessing pronunciation (verbal narrative), syntax, and vocabulary range.

The storytelling skills are progressing achievements, their acquisition starts from early childhood; from that point on, it becomes a manifestation of the child's linguistic creativity (Bokus, 1991, p. 19). In the maturing process, a child develops cognitive (perception, memory, thinking) (Soroko \& Wojciechowska, 2015, p. 217) and linguistic competence. At that stage, children also acquire and improve their narrative competence, which is considered to be the fundamental aptitude of human brain (Wyrwas, 2014 pp. 11-12). The most intensive development of narrative competence occurs between the age of two and seven, and along with shaping it, the child is able to create more and more complex stories (Bokus, 1991, p. 19). This overall competence emerges when the child listens to stories and then attempts to create their own. Hence, a cognitive representation of implicit narration is formed in the mind of the child (Kielar-Turska, 2018, 
p. 220). The child's narrative skills grow significantly by the age of seven, and then, by the age of ten they are perfected. It goes without saying that school education, during that period of time substantially, facilitates this progress (ibidem) ${ }^{2}$.

Many researchers, developmental psychologists (e.g. Bokus, 1991; Kielar-Turska, 1989), teaching theorists (e.g. Jóźwicki, 1984; Nagajowa, 1977, 1990; Węglińska, 1997), agree that it is necessary to enrich the knowledge of storytelling and to continuously train the narrative ability by means of numerous vocabulary, phraseological, grammatical, and stylistic exercises, and by familiarising and explaining the essence of a story and the necessity to include the presented events in a complete, hierarchical structure since, as Maria Kielar-Turska (1989) points explicitly, as long as the child does not grasp the elements of the structure, they are capable of creating only fragmentary or even chaotic statements. Therefore, the familiarity with the full structure of the narrative form facilitates understanding and recreating of stories. This "know-how" fosters one's perception and helps to create new stories (Kielar-Turska, 1989, p. 108, 110). Consequently, aside from description and dialogue, storytelling is the core line of communicative and social skills development (Grabias, Kurkowski \& Woźniak, 2002, p. 9); on the one hand, it influences the way children acquire such school skills as reading and writing, and, on the other, it affects the quality of life in social groups (Przybyla, 2018, pp. 306-316).

Narrative, according to Grabias, is the most difficult form of human linguistic activity. It endorses mental capabilities of a person. It has a closed and yet intricate internal composition. Recreating all components of the narrative and presenting them in temporal, causal, and spatial orders attests the full mental capacity of a person (Grabias, 2015, p. 22). As the studies on the speech of people with various disorders show (e.g. in Alzheimer's disease, schizophrenia, aphasia), their narrative ability is lost, limited, or completely disintegrated (Grabias, 2015, p. 24).

In his research, Tomasz Woźniak demonstrates that people suffering from schizophrenia (even though this might depend on the type of the disorder), do not develop such skills at all or acquire them in an inconsistent, incomplete,

2 Arthur Applebee (1978 in Bokus, 1991, pp. 25-26) distinguishes six stages of narrative structure development: early pre-narrative forms (a child's linguistic activity amounts to mere reporting of what they see at a given moment, which draws attention to them, yet they fail to merge illustrations / figures into cause-effect relation); associative sequences (a list of events collected not in chronological or causal terms, but by means of some common features that connect given objects or characters); primitive narrative (creating a story set on some permanent element of the narrative, e.g. on the main character or an event; at the end of this type of narrative, there is an assessment of a character or an event); unfocused chains (the events depicted are logically or causally related, but the narrative continuity is not yet preserved); focused chains (the presented events are logically liaised by a protagonist and they maintain the cause-effect relation; however, there is no presentation of the character's goal, there is no clear ending of the story, or such an ending is inconsistent with the initial content of the story); true narrative (events are combined into a logical and coherent whole, the protagonist's goal is presented, and the ending of the story refers to its beginning). 
or disintegrated manner; therefore, their narratives are simplified or informatively impoverished, whereas the presented events are sometimes misinterpreted (Woźniak, 2005, p. 129, 204). The complex utterances of schizophrenia patients fail to exhibit coherence, and thus their narrative plan, as the events are fairly disturbed when it comes to their cause-effect or temporal relations, or the prevailing idea the narrative presents. Woźniak notices that the patients are capable of acquiring individual facts, but they either experience a great difficulty in arranging them into meaningful, larger whole or adopt rules diverging from those that are socially accepted (ibidem, p. 207). The narrative consistency interference prevents schizophrenia patients from correct interpretation of reality, and, in the long-run, it affects their quality of social life.

In her research on language, interactions, and aphasia, Jolanta Panasiuk proves that an individual displaying insufficient linguistic, communicative, and cultural competences might develop a compensating strategy. Aphasia patients are capable of developing all types of utterances, be it texts, non-texts, or, most commonly, pathological texts with disturbed substantial layer, grammatical, and semanticpragmatic coherence. Generally speaking, their narrative is limited by lexical, grammatical, and syntactic issues; although the same patients exhibit different levels of efficiency in creating a description or a story, in colloquial conversations, they use a dialogue-specific structure that primarily changes the proportions of interlocutors' activity. People with aphasia are less likely to initiate a conversation, and, if communicating, they are rather provoked by the situational context. Moreover, they tend to loosen the dialogue's major line and introduce new topics into a conversation (Panasiuk, 2013, p. 207, 311).

According to Grażyna Jastrzębowska (2003, p. 10), despite properly developed language competences, communicative speech disorders may also distort utterances. For example, as Zbigniew Tarkowski shows, content and consistency of spoken communication in stuttering people are disordered (Tarkowski, 1987, p. 10). Thus, the higher the intensity of speech disfluency symptoms, the more increased disfluency in dialogical and narrative statements is, especially in complex syntactic structure (Tarkowski, 2017, pp. 124-125). Therefore, in case of stuttering, communicative difficulties interrupt the fluency of the phonic sequence, which impedes reconstructing semantic and grammatical shape of an utterance (Panasiuk, Woźniak in: Faściszewska, 2020, p. 105). Similarly, while researching stuttering people and the way they create dialogical and narrative statements, Maria Faściszewska concludes that the excess of repetitions, unnatural extensions, blocks, and, especially, embolophrasia, that is, the exaggerated number of interludes or prolonged sounds, initially inhibits developing a good text, and thereafter, handicaps the subsequent understanding of the message. Interestingly, the examination showed higher severity of narrative disfluency symptoms versus dialogue in women, while stuttering men maintain a similar level of both forms 
of expression. Eventually, stuttering hinders the development of a story as it often reduces it to a very short, one-word statement with limited semantic content and structure $^{3}$. Faściszewska claims that longer expression difficulties may be a reason of a serious speech-phobia, impaired fluency, increased blocking, and insufficient language skills and competences (Fraściszewska, 2020, p. 141, 204, 212).

The issue of spoken and written language mastering difficulty does not amount to the dominance of hearing or speaking deficiencies. Bilingual or multilingual children often struggle in acquiring apt levels of speaking and writing competence, since even slight developmental disturbances, such as cross-lateralisation or phonemic hearing disorders, might make these children, who are learning two different codes, exhibit inhibited language formation (Cieszyńska, 2013, p. 166). It, inevitably, leads to a detained or insufficient development of the skill to build grammatically, semantically, and lexically correct statements. Bilingual children's ability to create narrative texts (stories and descriptions) is diminished as the latter usually contain single words, portmanteau, or simple sentences utterances, and reveal numerous inflectional and syntactic errors, whereas the narrated events are deprived of logical consistency or cause-effect relation (Błasiak-Tytuła, 2015, pp. 140-143).

Moreover, parents of bilingual children falsely believe that timing discrepancy in mastering inflectional and syntactic skills in native language versus the country-of-residence language is a natural phenomenon (Cieszyńska, 2013, p. 171). On the contrary, in order to ensure proper development of language and communication skills of the bilingual child, we must provide an adequate quantity and quality of stimulus of both languages being acquired (OrłowskaPopek \& Błasiak-Tytuła, 2017, pp. 158-159) since the language acquisition is not about switching codes and using unknown words in native language, but rather it is about adopting the temporal, social, and cultural context (Cieszyńska, 2013, p. 173) so that the linguistic competence limitations do not affect the intellectual, emotional, and social development of a young person. As the research of Jagoda Cieszyńska shows, the children of Polish emigrants who were sent to the nursery at the age of 18 months, failed to fully develop linguistic system, both in speech and writing in any of their languages by the age of 12 (Cieszyńska, 2013, p. 175).

Speech therapy experiences demonstrate that the normal development of narrative skill follows specific patterns, mastering of which is not always possible. For this reason, the narrative skill often becomes inaccessible to hearing impaired people, autistic children, or mentally disabled people (Grabias, 2015, p. 24).

\footnotetext{
${ }^{3}$ While the statements structure of stuttering people included orientation formula, the final one was often omitted to use coda such as: no to tyle, koniec [eng.: that's it, the end] (Faściszewska, 2020, p. 119)
} 
Hearing impaired people have a limited ability to naturally develop and assimilate the language system. As a consequence, this leads to difficulties in the sphere of linguistic and communicative competences, hindering, thus, social interaction with a wider audience (that is, not only with the hearing impaired people). Although there are alternative methods of communication, such as pictograms, phono-gestures, and sign language, speech allows for a much broader participation in social life, since language plays fundamental and most important role in interaction. Therefore, non-linguistic behaviours assign a person to a specific group (Grabias, 2019, p. 217). The pedagogical experience demonstrates quite a clear fact that without mastering speech first there is almost an impossibility to fluently master writing (Krakowiak, 2012, p. 223). According to Dryżałowska, hearing impaired people acquire writing along with speech but with impeded language skills; hence, in the writings of hearing impaired, there are many linguistic irregularities, bizarre expressions, simplifications of grammatical constructions (Dryżałowska, 2007, p. 68). For the hearing impaired people, the solution is therefore to learn a language in writing and speaking by being an active participant of hearing community - being a part of the world of sounds.

\section{Research Methodology}

Generally speaking, the research investigated hearing impaired hurdles when writing a narrative (story) of a five-element picture story. More importantly, the study aimed to reveal whether a person suffering from hearing impairment is capable of embracing storytelling structure and present, considering the cause-effect thread and the temporal aspect, that is, a part of reality in this form of narration.

The study involved a group of fifteen students of the University of Natural Sciences and Humanities in Siedlce attending the Polish language course for people with hearing impairment -6 women and 9 men. Four people did not use sign language at all, but communicated verbally (they underwent a cochlear implant surgery at different times of their lives - see Table 1). The other students used sign language as the primary means of communication (also they read lips). Following observations undertaken during the classes and reviewing students' verbal and written statements, it turned out that the group displayed an array of different levels of language competence. Interestingly, not always language proficiency was conditioned by more developed auditory perception. 
E. DziĘCIOŁ-Chlibiuk: Storytelling superstructure in the utterances...

TABLE 1. General characteristics of the study group

\begin{tabular}{|c|c|c|}
\hline 1. Number of RESPONDENTS & 15 & \\
\hline 2. GENDER of RESPONDENTS & 6 women & 9 men \\
\hline $\begin{array}{l}\text { 3. AgE DURING THE STUDY } \\
=20 \text { years } \\
=21 \text { years } \\
\text { " } 22 \text { years } \\
\text { " } 23 \text { years } \\
\text { " } 24 \text { years }\end{array}$ & $\begin{array}{l}2 \\
1 \\
- \\
1 \\
2\end{array}$ & $\begin{array}{l}1 \\
2 \\
1 \\
1 \\
4\end{array}$ \\
\hline $\begin{array}{l}\text { 4. TYPE OF HEARING IMPAIRMENT } \\
\text { " slight } \\
\text { " moderate } \\
\text { " significant } \\
\text { " deep }\end{array}$ & $\begin{array}{l}1 \\
3 \\
- \\
2\end{array}$ & $\begin{array}{l}1 \\
3 \\
1 \\
4\end{array}$ \\
\hline $\begin{array}{l}\text { 5. Time Of HEARING IMPAIRMENT } \\
\text { " prelingual } \\
\text { " perilingual } \\
\text { " postlingual }\end{array}$ & $\begin{array}{l}6 \\
- \\
-\end{array}$ & $\begin{array}{l}6 \\
2 \\
1\end{array}$ \\
\hline $\begin{array}{l}\text { 6. TyPE OF SCHOOL } \\
\text { " general school } \\
\text { " school for the hearing impaired } \\
\text { " at the beginning general school, then scho- } \\
\text { ol for the hearing impaired (high school, } \\
\text { technical college) }\end{array}$ & $\begin{array}{l}5 \\
1 \\
-\end{array}$ & $\begin{array}{l}4 \\
4 \\
1\end{array}$ \\
\hline $\begin{array}{l}\text { 7. HEARING APPARATUS } \\
\text { - hearing aid } \\
\text { " cochlear implant }\end{array}$ & $\begin{array}{c}2 \\
4 \\
\text { (since the age of } 8 ; \\
\text { since the age of } 10 \\
\text { and since the age of } 20 \text { ) }\end{array}$ & $\begin{array}{c}7 \\
2 \\
\text { (since the age of 15; } \\
\text { since the age of 4) }\end{array}$ \\
\hline $\begin{array}{l}\text { 8. Preferred Communication } \\
\text { " } \text { speech (phonic) } \\
\text { " } \text { sign language + lip reading } \\
\text { " } \text { speech + sign language }\end{array}$ & $\begin{array}{l}5 \\
1 \\
-\end{array}$ & $\begin{array}{l}3 \\
6 \\
-\end{array}$ \\
\hline $\begin{array}{l}\text { 9. HEARING LOSS IN THE FAMILY } \\
\text { " only the examined person } \\
\text { " test person and parents } \\
\text { " test person and siblings }\end{array}$ & $\begin{array}{l}2 \\
- \\
4\end{array}$ & $\begin{array}{l}7 \\
- \\
2\end{array}$ \\
\hline
\end{tabular}

Source: Own study. 
The students worked individually or in the teams of two; in case of students using only sign language, the research was carried out in the presence of Halina Grzeszczuk, the sign language interpreter. First, the students were provided with a five-element picture stor $y^{4}$ with a request to carefully examine the illustrations. Then, they were asked to arrange the pictures in the right sequence (the beginning, middle and end of the story).

In the second part of the study, the students were to independently create a narrative (story) including its sequencing. They had been briefed to apply an appropriately structured story including introduction, body, and ending, and to tell what happened to the boy on the pictures, but not to describe individual pictures. Although that instruction seems to be somewhat extensive, many researchers (Kołodziejczyk, 2015; Krakowiak, 2012; Rakowska, 1992) claim that that people suffering from hearing impairment exhibit difficulties in creating a narrative; thus, they may need more thorough explanation.

The guideline to analyse the story superstructure was Stanisław Grabias's model (2015, pp. 22-23) distinguishing following elements:

- orientation - clauses beginning the story;

- exposition - clauses presenting the situation;

- complication - presenting the climax of the story;

- resolution - a way out of a complication;

- coda - clauses ending the story.

Almost all respondents completed the task included in the first part of the research without a single mistake; they managed to easily arrange, maintaining the sequence of both time and cause-effect thread, individual elements of the picture story. One person arranged the pictures in wrong order; precisely, she put the last picture at the beginning of the story, which changed the whole content.

At the start of the second part of the study - telling the narrative, five students first, pointing at specific element in the picture asked for its name using its description e.g. to coś, co jest [o]puszczane, jak jedzie pociag [eng.: this thing that is lowered/released, when the train goes]. None of the respondents kept the proper format of the text, or divided it into three constitutive elements: introduction, body, and ending. Three people numbered the individual pictures and properly almost bullet-pointed their utterances, describing each illustration without; however, the use of lexemes linking the course of events into a coherent whole, e.g. (a) 1. Chłopiec i dziewczynka jechali na rowerem do szkoły, droga przez tora a zapora zamknęła w czasie jeździ pociagiem.

${ }^{4}$ In this research, a 5-element picture story was used, based on Co się stanie? Historyjki obrazkowe series [eng.: What will happen? Picture Stories], Schubi Publishing House. The idea was to select an apt, not too immature story for the students, which would be interesting and unusual: a story that, apart from enabling noticing the cause-effect relations, will also allow for reference to emotions and the evaluation of the protagonists' behaviour. 
2. Chłopiec z niebieskie kurtkę nie chciał czekać z rowera tylko zostawił oparcie za pomoca zapora. I przyszedt drugi kolega, pokazał swoje umiejętności z rowerem. (b) 3. Ostatni kolegi zwolnić szlaban i rower podniesieć szlabanem. 4. Został pod drzewem bo rower wisi szlabanem. 5. Przyjechał najpóźniej do szkoły ${ }^{56}$. One student has written down the whole story as a single complex clause with a subordinate sentence without any punctuation marks, in which the conjunctions ( $i, a$ [eng.: and, so]) and the opposite (ale [eng.: but] ) separated individual components of statement:

Pewnego dnia chłopca $w$ niebieskim kurtce jezdził rowerem $z$ koledzy $i$ tam był zabora pociagiem który zamkną i ten chtopiec zostawit rowerem przy zaborze i gadat z kolegami a jak pociag już odjechała i zabora zaczyna otwierać ale z rowyzonym rowerem do góry a koledzy musieli zostawić kolegi w niebieskim kurtce ponieważ nie moga spóźnić na lekcja a tam niebieskim kurtce musiat poczekać aż zabora będzie zamknięta izabrać rowera i py[unreadable] do szkoty ale nie stety spóźnił na lekcji ${ }^{7}$.

${ }^{5}$ I keep the original spelling and format of the cited examples of respondents.

${ }^{6}$ Translator's note: (a) 1 . The boy and the girl were cycling ( $\mathrm{t} / \mathrm{n}$ : wrong correlation between the prepositions $n a($ on) and conjugated word rowerem (bike)) to school, the road through the track $(\mathrm{t} / \mathrm{n}$ : wrong conjugation tora (track)) and the barrier closed in time goes a train [t/n: zamknęła (closed) and jeździ (goes) are presented in mixed tenses]. 2. Translator's note: The boy with the blue jacket ( $\mathrm{t} / \mathrm{n}$ : wrong preposition $\mathrm{z}$ (with) it should be $\mathrm{w}$ (in/wearing) and niebieskie kurtke (blue jacket) is not conjugated correctly) did not want to wait with the bike [t/n: czekać $z$ rowera (wait with bike) is wrongly conjugated) but left the support with a help of barrier ( $\mathrm{t} / \mathrm{n}$ : zapora(barrier) is not properly conjugated to agree with its correlation za pomoca (with a help of) and the context is ambiguous). And another friend came, he showed his skills with a bicycle. (b) 3. The last friend release the barrier and lift ( $\mathrm{t} / \mathrm{n}$ : poniesieć (lift) this words is wrongly spelled) the bike with the barrier ( $\mathrm{t} / \mathrm{n}$ : not conjugated correlation between ostatni kolegi (last friend) and lack of link between ostatni kolegi zwolnić szlaban (last friend release barrier) as well as there is no tense correlation that makes the clause awkward and incomplete. 4 . He stayed under the tree because the bicycle hangs with a barrier ( $\mathrm{t} / \mathrm{n}$ : no proper prepositional correlation and wrong conjugation, used szlabanem (barrier) and mixed tenses zostat (stayed) and wisi (hangs)). 5. Arrived at school the latest.

7 Translator's note: One day boy in a blue jacket ( $\mathrm{t} / \mathrm{n}$ : w niebieskim kurtce (in blue jacket) is expressed with wrong conjugation) rode his bicycle with friends ( $\mathrm{t} / \mathrm{n}: \mathrm{z}$ koledzy (with friends) not proper conjugation with preposition $\mathrm{z}($ with $)$ ) and there was a barrier $(\mathrm{t} / \mathrm{n}$ : hearing impaired display difficulties differentiating sound (b) and voiceless ( $\mathrm{p}$ ) consonants and so instead of zapora(barrier) zabora is used) with train which closed ( $\mathrm{t} / \mathrm{n}$ : pociągiem który zamknął (with train which closed) the phrase has wrongly conjugated zabora pociągiem (barrier with train) and który zamknął (which closed) makes reference to the train closing the barrier not the barrier closing when the train arrives) and the boy left bicycle ( $\mathrm{t} / \mathrm{n}$ : wrong conjugation zostawił rowerem (left bike) near the barrier and talked with his friends and when the train has already left $(\mathrm{t} / \mathrm{n}$ : train in this phrase is wrongly considered a feminine gender and is correlated with past form feminine gender odjechała (left) and the barrier begins to open, but with the bike ( $\mathrm{t} / \mathrm{n}$ : rowyzonym it is a non-existing created word that probably means - going up) going up and friends had to leave their friend ( $t / n$ : kolegi(friend) is in accusative and it should be in genitive case) in the blue jacket ( $\mathrm{t} / \mathrm{n}$ : jacket is feminine gender and here the adjective blue conjugated as if masculine) because they cannot be late for the lesson $(\mathrm{t} / \mathrm{n}$ : 
This example of the story's syntactic structure reveals certain weakness hearing impaired people display. They have merely reported observed elements without a consistent and smooth transition between them.

Three respondents used the story's commencing clause composing the phrase - pewnego dnia [eng.: one day] and two people used a more extensive introduction - Był piękny, słoneczny dzień...; pewnego, słonecznego dnia [eng.: It was a beautiful, sunny day...; one sunny day]. The other six students started their narrative with the exposition element, outlining the general content of the whole situation without setting it in time, e.g. Chłopiec jechał ze swoja koleżanka na rowerach do szkoty [eng.: the boy with his friend were riding bikes to school]; Chłopiec $z$ niebieskimi kurtka $z$ znajomi jechali rowerem do szkoły [eng.: The boy with the blue jacket and his friends were cycling to school]; Chłopiec wraz koleżanka wybrat się na przejażdżke rowerowa do szkoły... [eng.: The boy and his friend went for a bike ride to school...]. Out of the fifteen respondents, seven jumped into reporting the events in the introductory part of the story e.g. Dzieci podjeżdzaja pod bocznice kolejowej [eng.: Children drive up to a railway siding]; Dwójka przyjaciót stoja przed przejazdem [eng.: Two friends are standing in front of the crossing]; Pewnego dnia chłopiec i dziewczynka zatrzymuja sie przy szlabanie [eng.: One day a boy and a girl stop by the barrier]; Kolego jeździli rowerami przed kolegem i zatrzymali sie [eng.: Buddy, they rode their bikes in front of a friend and stopped].

TABLE 2. Numerical elements of the structure of the story in written works by people with hearing impairment

\begin{tabular}{|l|c|c|c|c|}
\hline \multirow{2}{*}{$\begin{array}{c}\text { Elements of story } \\
\text { structure }\end{array}$} & \multicolumn{2}{|c|}{$\begin{array}{c}\text { Respondents incorporating } \\
\text { given component } \\
\text { into their structure }\end{array}$} & $\begin{array}{c}\text { Respondents failing to incorporate } \\
\text { given component } \\
\text { into their structure }\end{array}$ \\
\cline { 2 - 5 } & [pers. / 15 pers.] & {$[\%]$} & [pers. / 15 pers.] & {$[\%]$} \\
\hline Orientation & 5 & 33 & 10 & 67 \\
\hline Exposition & 6 & 40 & 9 & 60 \\
\hline Complication & 13 & 87 & 2 & 13 \\
\hline Resolution & 12 & 80 & 3 & 20 \\
\hline Coda (End) & 2 & 13 & 13 & 87 \\
\hline
\end{tabular}

SOURCE: Own study.

lekcja (lesson) should be in accusative and it is in nominative case) and there, the blue jacket had to wait until the barrier will be closed and take the bike and ask $p y$ [unreadable] to school but was unfortunately late $(\mathrm{t} / \mathrm{n}$ : abrupt expression of the word niestety (unfortunately) for the lesson $(\mathrm{t} / \mathrm{n}$ : wrong case, it should be nominative). 
Although thirteen students had noticed the culminating event, which significantly influenced the course of the described story, some of them presented it in a form of a simple but extended sentence while others used two or more clauses. Moreover, written compositions of students with auditory disabilities focused mainly on the complication part, elaborating it both in content and syntax, hence in $75 \%$ of texts complication surpassed greatly any other elements. For example: Kiedy pociag przejechał jeden z chłopców, który oparł rower o szlaban nie pomyślat ze szlaban po przejechaniu pociagu może się podnieść się wraz z jego rowerem [eng.: When the train passed, one of the boys who leaned the bicycle over the barrier, did not think that the barrier, after the train has passed, may go up with his bicycle]; Czekając, chłopiec postawił swój pojazd przy szlabanie i spotkał innego znajomego z klasy, który też spieszył się na lekcje. Nagle szlaban się podnióst, i razem $z$ nim... rower chłopca [eng.: While waiting, the boy parked his vehicle by the barrier and met another classmate who was also in a hurry to attend lessons. Suddenly the barrier lifted, and with it... the boy's bike]; [...] chłopiec z niebieskim kurtka zostawił na zaporem, rozmawiał z znajomi, czekał aż zapór otwiera [eng.: [...] the boy with the blue jacket left at the barrier, talked to his friends, waited for the barrier open] ${ }^{8}$. [...] Pociag już jechat, a zapór otwierat. Zapór wisat rower [eng.: [...] The train was on its way and the barrier opening. A barrier hung a bicycle $]^{9}$; Czekając pozostawił rower przy zaporze, przyjechat kolega. Koleżanka zauważyła jak zapora podniosła się wraz z rowerem [eng.: While waiting, he left his bike at the barrier and a friend came. A friend noticed how the barrier rose with the bicycle]; Chłopiec został rampy, a reszte trzymali rowera. Rozmawiali. Ona krzyczała go, że patrzyć nagle rampa otwierała wysiać rowera do góry [eng.: The boy was ramped and the rest kept the bicycle. They were talking. She was screaming him to see suddenly the ramp was opening send the bike up $]^{10}$.

The resolution element of the story superstructure was applied by 12 respondents. It is clear that both components i.e. complication and resolution appear

${ }_{8}$ Translator's note: [...] the boy with the blue jacket ( $\mathrm{t} / \mathrm{n}$ : the pronoun $\mathrm{z}$ (with) normally would be replaced by w(in) meaning - wearing; adjective and noun - blue jacket are wrongly conjugated) left ( $\mathrm{t} / \mathrm{n}$ : missing noun - bike) at the barrier, talked to his friends, waited for the barrier open $(\mathrm{t} / \mathrm{n}$ : in Polish is the wrong word order and form so the phrase is barely understandable).

9 Translator's note: The train was on its way and the barrier opening $(\mathrm{t} / \mathrm{n}$ : in Polish otwiera(open) is in reflexive (się(itself) form). A barrier hung a bicycle ( $\mathrm{t} / \mathrm{n}$ : wrong word order and missing preposition e.g. A bicycle was hanging from the barrier).

${ }_{10}$ Translator's note: The boy was ramped ( $\mathrm{t} / \mathrm{n}$ : $\operatorname{rampy}($ barrier) is missing preposition (maybe it was: the boy stayed at the barrier) and so there is a confusion if it is used as a noun or a verb) and the rest $(\mathrm{t} / \mathrm{n}$ : rest $($ reszte $)$ is in the wrong cause it should be nominative) kept the bicycle $(\mathrm{t} / \mathrm{n}$ : bike(rowera) is in the wrong case, it should be nominative). They were talking. She was screaming him $(\mathrm{t} / \mathrm{n}$ : missing preposition at $(n a))$ to see $(\mathrm{t} / \mathrm{n}$ : it is meant as a caution - to see what is happening) suddenly the ramp was opening send $(\mathrm{t} / \mathrm{n}$ : this a proposition translation suggestion since the original uses sieve(wysiać) that normally refers to seeds) the bike up. 
in most compositions of the hearing impaired based on a specific narration of facts. Thus, the texts seemed thematically consistent by means of the preserved chronology of events. However, there was a prevailing tendency to describe individual illustrations instead of approaching them globally as elements of a complex unity. Perhaps that was one of the reasons, only in four compositions, the hearing impaired students applied only few conjunctions of time i.e. po chwili, potem, nagle [eng.: after a while, then, suddenly] or cause and effect ones. Furthermore, students presented events using different tenses often mixed and so 12 texts displayed jumbled present and past e.g. Chłopiec nie zdaczył go zabrać. Gdy brama nie została zamknięta rower nadal jest na górze. Chłopiec czeka aż zamkna brame żeby mógł zabrać rower [eng.: the boy did not manage to take it. When the gate has not been closed the bicycle is ( $\mathrm{t} / \mathrm{n}$ : tenses mixed) still up. The boy waits for the gate to close so that he can take the bike]; Chłopiec $z$ zielona kurtke i dziewczynka pojechali, a drugi chłopiec leży i czeka aż pociag przyjedzie wtedy opuści zaporami. W końcu chłopiec dotart do szkoły, opowiada nauczyciel o swoja sytuacje przez tego spóźnił [eng.: The boy with the green jacket and the girl have gone, and the other boy is lying and waiting for the train to arrive then close the barriers. In the end the boy reached school, tells the teacher about his situation because of its he was late ${ }^{11}$; Oni pojeździli do szkoły a on leżał przy drzewa i czekat. Już po dołu rampy wzią tego i jeździł do szkoły [eng.: They we going to school and he laid by tree and waited. Already after the bottom of the ramp he picked it and was ridding it to school] ${ }^{12}$; Po przejeździe szlaban podnosi się do góry na którym opiera się rower. Dzieci pojechały do szkoły, a chłopiec musi czekać na następny pociag, aby odebrać rower $z$ szlabanu [eng.: After train passing, the barrier rises up on which the bicycle rests. The children have gone to school and the boy has to wait for the next train to pick up the bike from the barrier].

The majority of students (13) failed to use the story's ending formula either in verbal or written form. The coda element was applied by two people, one captured it in the form of a simple - koniec [eng.: the end], and the other wrote it in

${ }^{11}$ Translator's note: The boy with the green jacket ( $\mathrm{t} / \mathrm{n}$ : wrong preposition should be in (meaning - wearing) and the girl have gone, and the other boy is lying and waiting $(\mathrm{t} / \mathrm{n}$ : mixed tenses) for the train to arrive then leave the barriers ( $\mathrm{t} / \mathrm{n}$ : the awkwardness is due to lack od passive form - the barrier will be closed). In the end the boy reached school, tells the teacher ( $\mathrm{t} / \mathrm{n}$ : mixed tense, wrong case, it should be dative) about his ( $\mathrm{t} / \mathrm{n}$ : even though the pronoun seems correct in English, Polish needs the pronoun conjugated) situation ( $\mathrm{t} / \mathrm{n}$ : wrong case) because of its ( $\mathrm{t} / \mathrm{n}$ : wrong usage of a pronoun its(tego)) he was late.

12 Translator's note: They we going to school ( $\mathrm{t} / \mathrm{n}$ : continuous past action when it should be simple past) and he laid by trees ( $\mathrm{t} / \mathrm{n}$ : wrong case should be locative) and waited. Already after the bottom ( $\mathrm{t} / \mathrm{n}$ : wrong preposition after $(p o)$ should be $\mathrm{u}(a t))$ of the ramp he picked it and was ridding $(\mathrm{t} / \mathrm{n}$ : mixed tenses continuous instead of simple past) it to school. 
a form of a summary outlining the emotional downside of the main character: Podsumowując, ten dzień był jednym z gorszych okresów w życiu chłopca, gdyż ta sytuacja został wyśmiany przez swoich rówieśników i przez spóźnienie się dostał uwage od nauczyciela [eng.: To sum up, this day was one of the worst periods in the boy's life, as he was laughed at by his peers and by being late he got attention from the teacher].

\section{Conclusions}

The collected material shows that arranging a picture story using time and causeeffect sequence poses no difficulty to hearing impaired but developing a flowing, coherent written text embedded in the full, hierarchical superstructure of the story is a serious challenge many of the respondents failed to accomplish. Orientation and coda were the most often overlooked compositional elements of the story while the culminating event and the resolution were properly presented in the studied narratives. This research demonstrates that hearing impaired people are capable of noticing sequence of related events, but they were unable to combine them into a coherent, logical unity. Additionally, due to the disability, all narratives displayed numerous inflectional and syntactic errors which impeded fluency between the elements of the presented reality. A significant part of the stories told by the students with hearing disabilities included colloquial language and shorthand; hence, the narrator was able to account on only the most important elements of the event, missing out descriptions of the place and action or the appearance of the characters. On top of that, students used fewer lexemes as well as expressions describing time relations and the manner of carrying out the activities presented in the story. In the written texts of the hearing impaired students, the prevalence of simple, extended simple and complex (paratactic) sentences is obvious compared to few stories that included subordinate (hypotactic) clauses in their syntactic structure. This phenomena, perhaps, could be explained following Aldona Skudrzyk and Jacek Warchala's work (2010), where they demonstrate the advantage of parataxis over hypotaxis in school youths written works as a proof of changed approach i.e. the conceptualisation of the world applying concrete thinking, blocking the emergence of abstract thinking and discouraging reflection and interpretation.

Hipotaksa [...] nakłada na świat siatkę relacji przestrzenno-czasowych, pokazuje elementy świata we wzajemnych związkach i relacjach; parataksa natomiast ujawnia myślenie w kategoriach współistnienia równorzędnych elementów i stanów rzeczy 
ułożonych (pomyślanych) linearnie. [...] Parataksa jest rodzajem skanowania świata, podczas gdy hipotaksa interpretuje świat (Skudrzyk \& Warchala, 2010, s. 64) ${ }^{13}$.

\section{Summary}

Having reviewed all the available data it is intelligible to say that exercises shaping the ability to develop stories should be included in the integration education as well as in programming speech therapy of hearing impaired people. Therefore, in addition to phraseological exercises enriching the vocabulary as well as inflectional and syntactic (especially in forming extended simple, compound and especially complex clauses) practice, deepening and developing knowledge about the story and its full, hierarchical structure appears to be of key importance (Przybyla, 2018, pp. 221-222). Maria Kielar-Turska’s team (2018, pp. 221-222) demonstrated that children exhibiting better implicit cognitive representation, awareness of narrative features could verbalise this knowledge. Eventually, it translated into a higher level of explicit cognitive representation of a narrative resulting in arranging longer, clearly sequenced, complete and organised structure.

The story-making fluency reflects the level of linguistic and communication competence and allows an individual to contribute to social life. Moreover, according to Maria Kielar-Turska (2018, p. 221), this form of narration evokes many emotions, provokes reflection, and, above all, provides people with knowledge about the world and shows the vital elements of it. It also allows for the formation of abstract thinking, as it develops imagination, prompts reflection and drawing conclusions. Therefore, providing hearing impaired people with the ability to express themselves in a form of a story is a crucial task of any tutor or therapist.

13 Translator's note: Hypotaxis [...] imposes a network of spatial and temporal relations on the world, and presents its constituents as they exist in relations and linkages; parataxis discloses thinking as the coexistence of equal elements and states of objects, as they are placed - or thought - in a linear sequence [...]. Parataxis is a way of scanning the world, whereas hypotaxis interprets it. 


\section{References}

Bokus, B. (1991). Tworzenie opowiadań przez dzieci. O linii i polu narracji. Kielce: Energeia.

BŁAsıAK-TytuŁa M. (2015). Narracja a rozumienie u dzieci dwujęzycznych. In: M. BŁAsıAK-TytuŁa, M. Korendo, \& A. Siudak (eds.), Nowa Logopedia. Rozumienie - diagnoza i terapia, vol. 6 (pp. 135-145). Kraków: Collegium Columbinum.

CieszyńsKa, J. (2013). Metoda Krakowska wobec zaburzeń rozwoju dzieci. Z perspektywy fenomenologii, neurobiologii i językoznawstwa. Kraków: Wydawnictwo Centrum Metody Krakowskiej.

Dereń, E. (2005). Opis a opowiadanie: typowe słownictwo szkolnych form wypowiedzi. Nauczyciel i Szkoła, 3-4(28-29), 145-159.

DryżaŁowska, G. (2007). Rozwój językowy dziecka z uszkodzonym stuchem a integracja edukacyjna. Model kształcenia integracyjnego. Warszawa: Wydawnictwo Uniwersytetu Warszawskiego.

DziĘCIOє-Chlibiuk, E. (2019). Realizacja struktury opisu na podstawie wypowiedzi ustnych i pisanych osób z uszkodzonym słuchem. Logopedia Silesiana, 8, 209-232.

Faściszewska, M. (2020). Jąkanie. Wypowiedzi dialogowe i narracyjne osób jąkających się. Gdańsk: Wydawnictwo Uniwersytetu Gdańskiego.

Grabias, S. (2012). Teoria zaburzeń mowy. Perspektywy badań, typologie zaburzeń, procedury postępowania logopedycznego. In: S. Grabias, \& Z.M. Kurkowski (eds.), Logopedia. Teoria zaburzeń mowy (pp. 15-71). Lublin: Wydawnictwo Uniwersytetu Marii Curie-Skłodowskiej.

Grabias, S. (2015). Postępowanie logopedyczne. Standardy terapii. In: S. Grabias, J. Panasiuk, \& T. WoźNiak (eds.), Logopedia. Standardy postępowania logopedycznego (pp. 13-35). Lublin: Wydawnictwo Uniwersytetu Marii Curie-Skłodowskiej.

Grabias, S. (2019). Język w zachowaniach społecznych. Podstawy socjolingwistyki i logopedii. Lublin: Wydawnictwo Uniwersytetu Marii Curie-Skłodowskiej.

Grabias, S., Kurkowski, Z.M., \& Woźniak, T. (2002). Logopedyczny test przesiewowy dla dzieci w wieku szkolnym. Lublin: Wydawnictwo Uniwersytetu Marii Curie-Skłodowskiej, Zakład Logopedii i Językoznawstwa Stosowanego, Polskie Towarzystwo Logopedyczne.

Jastrz̨̨воwska, G. (2003). Wprowadzenie. Problemy terminologiczne i definicyjne. In: T. GaŁKowski, \& G. Jastrzęвowska (eds.), Logopedia - pytania i odpowiedzi. Podręcznik akademicki, vol. 2 (pp. 9-36). Opole: Wydawnictwo Uniwersytetu Opolskiego.

Jóźwicki, T. (1984). Opowiadanie jako forma wypowiedzi w klasach poczatkowych. Warszawa: Wydawnictwa Szkolne i Pedagogiczne.

Kielar-Turska, M. (1989). Mowa dziecka. Słowo i tekst. Kraków: Wydawnictwo Uniwersytetu Jagiellońskiego.

Kielar-Turska, M. (2018). Dziecięca kompetencja narracyjna: rozumienie istoty narracji i umiejętność opowiadania. Studia Pragmalingwistyczne, 10, 211-224.

KoєODZIEJCZyк, R. (2015). Trudności gramatyczne u dzieci i młodzieży z uszkodzeniami słuchu. In: E. Muzy кA-Furtak (ed.), Surdologopedia. Teoria i praktyka (pp. 156-175). Gdańsk: Wydawnictwo Harmonia Universalis.

Krakowiak, K. (2012). Dar języka. Podręcznik metodyki wychowania językowego dzieci i młodzieży z uszkodzeniami narządu słuchu. Lublin: Wydawnictwo Katolickiego Uniwersytetu Lubelskiego.

Kulawik, A. (1997). Poetyka: wstęp do teorii dzieła literackiego. Kraków: Antykwa.

Kulpa, J., \& WiĘCKOWSKI, R. (1997). Formy ćwiczeń w mówieniu i pisaniu. In: M. WĘGLIŃsKa (ed.), Opowiadanie jako forma wypowiedzi w klasach początkowych (pp. 62-64). Kraków: Impuls.

Ky RC, B. (2018). Rozwijanie kompetencji narracyjnej dziecka dwujęzycznego w Polsce a jego sukces edukacyjny. Porównawcze studium przypadku. Języki Obce w Szkole, 4, 85-92. 
Malendowicz, J. (1997). Kształtowanie pisemnych wypowiedzi uczniów w klasach II-IV. In: M. WĘGLIŃsKa (ed.), Opowiadanie jako forma wypowiedzi w klasach początkowych (pp. 59-62). Kraków: Impuls.

Nagajowa, M. (1977). Ćwiczenia w mówieniu i pisaniu w klasach V-VIII szkoły podstawowej. Warszawa: Wydawnictwa Szkolne i Pedagogiczne.

Nagajowa, M. (1990). ABC metodyki języka polskiego dla początkujących nauczycieli. Warszawa: Wydawnictwa Szkolne i Pedagogiczne.

OrŁowska-Popek, Z., \& B£asiak-TytuŁa, M. (2017). Dziennik wydarzeń jako technika kształtowania kompetencji komunikacyjnej w sytuacji dwujęzyczności. Conversatoria Linguistica, 11, $157-170$.

PANASIUK, J. (2013). Afazja a interakcja. TEKST - metaTEKST - konTEKST. Lublin: Wydawnictwo Uniwersytetu Marii Curie-Skłodowskiej.

Przybyla, O. (2018). Kompetencja narracyjna uczniów z zaburzeniami rozwoju koordynacji. Logopedia, 47-2, 303-316.

RakowsкA, A. (1992). Rozwój systemu gramatycznego u dzieci głuchych. Kraków: Wydawnictwo Naukowe Wyższej Szkoły Pedagogicznej.

SKudrzyK, A., \& WARChalA, J. (2010). Kultura piśmienności młodzieży szkolnej - badania w perspektywie analfabetyzmu funkcjonalnego. Studia Pragmalingwistyczne, 2, 55-65.

Soroko, E., \& Wолсіесношsка, J. (2015). Kompetencja narracyjna jako obszar nauczania i oceny edukacji. Studia Edukacyjne, 37, 211-236.

TAR Kowski, Z. (1987). Jąkanie. Zagadnienia etiologii, diagnozy, terapii i prognozy. Warszawa: Wydawnictwo ZSL.

Tarkowski, Z. (2017). Jąkanie. In: Z. TARкowski (ed.), Patologia mowy (pp. 123-148). Gdańsk: Harmonia Universalis.

WĘGLIŃSKA, M. (1997). Opowiadanie jako forma wypowiedzi w klasach początkowych - istota, struktura. In: M. WęGLIŃsKa (ed.), Opowiadanie jako forma wypowiedzi w klasach początkowych (pp. 9-18). Kraków: Oficyna Wydawnicza Impuls.

Witosz, B. (1997). Opis w prozie narracyjnej na tle innych odmian deskrypcji. Zagadnienia struktury tekstu. Katowice: Wydawnictwo Uniwersytetu Śląskiego.

WolańsKa, E. (2010). Wykładniki spójności tekstów renarracji tworzonych przez młodzież szkolną w wieku 12-13 lat. Studia Pragmalingwistyczne, 2, 104-114.

Woźniak, T. (2005). Narracja w schiozofrenii. Lublin: Wydawnictwo Uniwersytetu Marii Curie-Skłodowskiej.

Wyrwas, K. (2014). Opowiadania potoczne w świetle genologii lingwistycznej. Katowice: Wydawnictwo Uniwersytetu Śląskiego. 
„Logopedia Silesiana”, t. 9, ISSN 2391-4297

https://doi.org/10.31261/LOGOPEDIASILESIANA.2020.09.08

s. 1-18: wersja angielskojęzyczna; s. 19-35: wersja polskojęzyczna

(c) BY-SA

\title{
Ewa Dzį̨CiOŁ-Chlibiuk
}

Instytut Językoznawstwa i Literaturoznawstwa, Wydział Nauk Humanistycznych, Uniwersytet Przyrodniczo-Humanistyczny w Siedlcach

(DD https://orcid.org/0000-0001-7034-0631

\section{Superstruktura opowiadania na podstawie wypowiedzi osób z uszkodzeniami słuchu}

\author{
Storytelling superstructure in the utterances of hearing impaired people
}

АвsтRACT: Storytelling, the most common form of shaping both linguistic and cultural texts, is the most frequently repeated pattern in interpersonal communication. The article dwells on the characteristics of this narrative expression, paying particular attention to its specific structure. Further on, the author provides a short description on how the narrative competence has been developing. The article includes the author's own research designed and performed to elicit challenges hearingimpaired people face when creating a written narrative text (story) based on a picture story, and to find an answer to the question on whether, in the mind of a hearing-impaired person, the storytelling structure exists. Finally, the author deduces that it seems reasonable, on the basis of the collected material, to assume that the integrated education as well as speech therapy of hearing-impaired people should include exercises shaping the ability to create stories as mastering this skill is connected with the level of linguistic and communicative competence.

KEYWORDS: storytelling superstructure, hearing-impaired people, narrative competence

STRESZCZENIE: Opowiadanie jest najpowszechniejszą formą kształtowania tekstów, nie tylko językowych, lecz także tekstów kultury. Jest najczęściej powielanym schematem konstruowania wypowiedzi w komunikacji międzyludzkiej. W artykule omówiono charakterystyczne cechy tej formy wypowiedzi narracyjnej, zwracając szczególną uwagę na jej strukturę. Podano krótki opis kształtowania się kompetencji narracyjnej. Przedstawiono wyniki badań własnych, których celem było sprawdzenie, jakie trudności sprawia osobom $\mathrm{z}$ wadą słuchu tworzenie tekstu narracyjnego (opowiadania) na podstawie historyjki obrazkowej, w formie pisanej. A przede wszystkim - czy w umysłach osób z uszkodzonym słuchem istnieje struktura opowiadania. Na podstawie zebranego materiału zasadne wydaje się założenie, że w kształceniu osób z niepełnosprawnością słuchową, jak także w programowaniu terapii logopedycznej, należy uwzględnić ćwiczenia z zakresu kształtowania sprawności budowania opowiadań. Opanowanie tej umiejętności świadczy o poziomie kompetencji językowej i komunikacyjnej.

SŁOWA KLUCZOWE: superstruktura opowiadania, osoby z uszkodzonym słuchem, kompetencja narracyjna 
Powszechnie przyjmuje się, że pełny udział w komunikacji, przekazie kulturowym, zdobywaniu wiedzy jest uwarunkowany opanowaniem języka i reguł posługiwania się nim. To dzięki językowi człowiek dokonuje konceptualizacji, strukturyzacji oraz interpretacji rzeczywistości, jej kategoryzowania i wartościowania (Cieszyńska, 2013, s. 164). Sprawność narracyjna jest jednym z elementów świadczących o poziomie rozwoju językowego, a przez to o obrazie rzeczywistości w umyśle ludzkim (Grabias, 2015, s. 22). Zasadne wydaje się zatem założenie, że analiza form narracyjnych (opisu i opowiadania) pozwala poznać sposób postrzegania rzeczywistości badanej osoby. Zgodnie z założeniami językoznawstwa kognitywnego oraz socjolingwistyki przez analizę tekstów narracyjnych, polegającą na ocenie elementów struktury języka i środków językowych, dostrzega się różnice, oryginalność normatywną lub nienormatywną w odbiorze świata i jego segmentacji (Dzięcioł-Chlibiuk, 2019, s. 218). Formy narracyjne są tekstami, które umożliwiają ocenę wszystkich podsystemów języka, kompetencji i sprawności językowych, komunikacyjnych, a także indywidualnych sposobów konceptualizacji wiedzy o świecie (Grabias, 2012, s. 62, 64). W celach diagnostycznych odróżnia się opowiadanie (umiejętność porządkowania zdarzeń w następstwie czasowym) od opisu ${ }^{1}$ (umiejętność ujmowania zjawisk w relacjach przestrzennych). Obie te formy wypowiedzi charakteryzują się odmienną strukturą i kompozycją (Grabias, 2015, s. 22).

\section{Opowiadanie - jedna z podstawowych form wypowiedzi narracyjnych}

Opowiadanie jest najpowszechniejszą formą kształtowania tekstów, nie tylko językowych, lecz także tekstów kultury. Jest najczęściej powielanym schematem konstruowania wypowiedzi w komunikacji międzyludzkiej. Jak zauważa Katarzyna Wyrwas, stanowi formę, która umożliwia oddanie upływu czasu i chronologii, dzięki czemu człowiek porządkuje chaotyczną rzeczywistość (w odniesieniu do zdarzeń, własnych doświadczeń), zaprowadza pewien ład, którego potrzebuje w celu zrozumienia siebie i świata (Wyrwas, 2014, s. 13). Według teorii literatury opowiadanie to relacja z tego, co się działo, prezentowanie jakiejś historii, zdarzeń. „Element narracji ujmujący dynamiczny aspekt świata przedstawionego, czyli

\footnotetext{
${ }^{1}$ Charakterystyczne cechy opisu jako jednej z form wypowiedzi narracyjnych omówiłam w swoim poprzednim artykule (Dzięcioł-Chlibiuk, 2019). W nim też przedstawiłam wyniki własnych badań nad umiejętnością realizacji struktury opisu na podstawie wypowiedzi ustnych i pisanych studentów $\mathrm{z}$ niedosłuchem $\mathrm{z}$ różnym stopniem ubytku słuchu.
} 
fabułę, którą z kolei zdefiniowano jako ciąg zdarzeń pozostających w związku przyczynowym” (Kulawik, 1997 s. 328). To „przedstawienie zdarzeń w ich chronologicznym i przyczynowo-skutkowym powiązaniu” (Nagajowa, 1990, s. 138). Jak podają Jan Kulpa i Ryszard Więckowski (1997), „opowiadanie przedstawia działanie, przebieg czynności i zdarzeń z zachowaniem ich następstwa, chronologii i z uwzględnieniem związków zachodzących między nimi” (s. 62). Według koncepcji Williama Labova i Joshuy Waletzky’ego (za: Bokus, 1991, s. 16) wyróżniamy trzy podstawowe elementy opowiadania: początek (wprowadzenie), środek oraz zakończenie, które składają się na makrostrukturę narracji. W skład jej mikrostruktury wchodzą komponenty akcji, czyli główni bohaterowie, postacie drugoplanowe, a także okoliczności, w których rozgrywają się zdarzenia (Kowal, 2006, za: Kyrc, 2018, s. 86).

Według metodyków przedstawiana treść powinna być zawierana w formie stanowiącej trójczłonową całość, na którą składa się wstęp, rozwinięcie i zakończenie, „przy jednoczesnym przestrzeganiu kolejnego wynikania wydarzeń i faktów” (Węglińska, 1997, s. 13). Wstęp nie musi być rozbudowany, może składać się nawet $\mathrm{z}$ jednego wypowiedzenia, które powinno zawierać ogólne informacje o przedstawianych zdarzeniach, określając też ich ramę czasową i przestrzenną. Rozwinięcie akcji to zrelacjonowanie samego zdarzenia $z$ dokładnym opisem jego przebiegu, następstw i ewentualnych konsekwencji. Tę część opowiadania powinien cechować barwny, żywy język. Zakończenie, podobnie jak wstęp, nie musi być bardzo rozbudowane, ale powinno stanowić wyraźne, jednoznaczne i czytelne rozwiązanie przedstawianej akcji. Może zawierać jakiś wniosek, morał czy ogólną myśl, która będzie podsumowaniem zaprezentowanych wydarzeń (Malendowicz, 1997, s. 60-61).

Według Marii Nagajowej (1977) opowiadanie związane jest z myśleniem wyobraźniowym opartym na emocjach (odczuwaniu, przeżywaniu i wartościowaniu), z tego też powodu w jego budowie składniowej przeważają zdania pojedyncze rozwinięte i złożone współrzędnie. „Ze zdań złożonych podrzędnie spotyka się zdania czasowe i przyczynowe, a to ze względu na cechy opowiadania, którymi są: następstwo w czasie oraz powiązanie wydarzeń w łańcuch przyczyn i skutków" (Nagajowa, 1977, s. 143). Ewa Wolańska (2010) podaje, że w opowiadaniu stosuje się głównie dwa typy operatorów międzyzdaniowych, które mają służyć uporządkowaniu zdarzeń w kolejności chronologicznej i przyczynowo-skutkowej. Należą do nich: operatory wskazujące następstwo w czasie - funkcję tę pełnią przysłówki, zaimki przysłowne i wyrażenia przyimkowe (np. najpierw, po chwili, początkowo) oraz operatory ustanawiające relację przyczyna - skutek, do których zalicza się wyrażenia spójnikowe (np. dlatego tė̇...) oraz rozwinięte grupy wyrazów (np. w wyniku...) (Wolańska, 2010, s. 110).

Cechami wyróżniającymi opowiadanie są przede wszystkim: dynamizm w przedstawianiu zdarzeń z zastosowaniem właściwych środków językowych 
(m.in. przysłówków oraz wyrażeń przyimkowych nazywających stosunki przestrzenne, np. potem, najpierw, wnet, zanim, wreszcie); stosowanie czasowników w czasie przeszłym dokonanym (w głównej mierze czasowników oznaczających czynności); przedstawianie wydarzeń w porządku chronologicznym; logiczność występujących po sobie faktów powiązanych wzajemnie zależnością przyczynowo-skutkową; używanie typowych wykładników spójności między wypowiedzeniami, np. następnie, potem, przedtem (Witosz, 1997, s. 23-24; Węglińska, 1997, s. 11); posługiwanie się odpowiednim słownictwem, m.in. określającym sposób wykonywania czynności (np. szybko, trafnie, z trudem, zabawnie, energicznie), określającym bohaterów, ich postawy oraz określającym czas (np. w czasie wakacji) i miejsce zdarzeń (np. na piaszczystej plaży) (Jóźwicki, 1984, s. 23; Dereń, 2005, s. 147).

Można wyróżnić różne typy opowiadania, m.in.: właściwe, informacyjne (dostarczające czytelnikowi dodatkowych informacji, które wyjaśniają, tłumaczą stan i zachowanie postaci); unaoczniające (pełniące funkcje dramatyzującą, uwierzytelniającą); okazjonalne (będące relacją przeszłych wydarzeń, likwidujące dystans między czasem dziania się wydarzeń a czasem opowieści o nich) (Kulawik, 1997, s. 328-329).

W edukacji szkolnej są uwzględniane przede wszystkim następujące typy opowiadań: odtwórcze (opowiadanie o wydarzeniach, o których się usłyszało lub przeczy tało - na podstawie lektury, filmu, przedstawienia teatralnego) oraz twórcze (wymyślanie na podstawie lektury zdarzeń związanych z postacią literacką; oparte na doświadczeniach narratora, nawiązujące np. do zdarzeń, których był świadkiem); twórcze i odtwórcze z użyciem dialogu (Dereń, 2005, s. 147; Nagajowa, 1990, s. 131).

Opowiadanie na przykładzie historyjki obrazkowej wymaga zastosowania odpowiednich, następujących zasad budowania wypowiedzi narracyjnej (Grabias, 2012, s. 62-63; Grabias, Kurkowski, Woźniak, 2002, s. 10, 27):

- rozpoznanie sytuacji odniesienia, wyznaczających historyjkę obrazkową; stanowią je elementy rzeczywistości, do których historyjka się odnosi: osoby, zwierzęta, zjawiska przyrody;

- ustalenie linii narracji: poukładanie sytuacji odniesienia w logiczny w miarę możliwości ciąg, wyznaczony układem przyczyn i skutków;

- wbudowanie linii narracji w strukturę opowiadania, która jako byt kognitywny podlega rozwojowi - superstruktura tekstu (inicjacja, ekspozycja, komplikacja, rozwiązanie, koda);

- dysponowanie umiejętnością ożywienia postaci przez nadawanie im cech psychicznych (ruch, emocje czynności, stany) - świadomość tzw. pejzażu psychicznego;

- dokonanie wyboru rodzaju narracji (miejsca narratora) - opowiadający może dysponować umiejętnością wejścia w rolę narratora (osoby kierującej akcją opowiadania); 
- zwrócenie uwagi na właściwy język wypowiedzi - ocena wymowy (w wypadku tekstu mówionego) oraz składni, zasobu słownictwa.

Człowiek uczy się opowiadać już we wczesnym dzieciństwie. Ta umiejętność staje się przejawem twórczej formy aktywności językowej dziecka (Bokus, 1991, s. 19). Wraz z rozwojem kompetencji poznawczej (spostrzegania, pamięci, myślenia) (Soroko, Wojciechowska, 2015, s. 217) oraz językowej nabywa też i udoskonala kompetencję narracyjną, która jest uważana za podstawową dyspozycję ludzkiego umysłu (Wyrwas, 2014, s. 11-12). Najintensywniejszy rozwój kompetencji narracyjnej przypada między 2. a 7. rokiem życia i z czasem dziecko jest w stanie tworzyć coraz bardziej rozbudowane opowiadania (Bokus, 1991, s. 19). Rozwój ten następuje na podstawie doświadczeń dziecka związanych z słuchaniem opowiadań oraz z pierwszymi próbami samodzielnego ich tworzenia. Wówczas w umyśle małego człowieka buduje się reprezentacja poznawcza narracji w formie ukrytej (Kielar-Turska, 2018, s. 220). Znaczne osiągnięcia w rozwoju sprawności narracyjnej dziecko wykazuje w 7. roku życia i są one doskonalone do 10. roku życia. W tym okresie istotną rolę odgrywa edukacja szkolna (Kielar-Turska, 2018, s. 220)².

Według badaczy, psychologów rozwojowych (m.in. Bokus, 1991; Kielar-Turska, 1989), metodyków nauczania (m.in. Jóźwicki, 1984; Nagajowa, 1977, 1990; Węglińska, 1997), należy rozwijać wiedzę o opowiadaniu oraz kształcić umiejętności tworzenia tej formy narracyjnej. Podkreślana jest ważność nie tylko prowadzenia wielu ćwiczeń słownikowo-frazeologicznych, gramatyczno-stylistycznych, ale też wyjaśniania istoty opowiadania oraz konieczności ujęcia przedstawianych wydarzeń w zamkniętą, hierarchiczną strukturę. Jak zauważa Maria Kielar-Turska (1989), dopóki dziecko nie uchwyci elementów struktury opowiadania, buduje wypowiedzi fragmentaryczne, a nawet chaotyczne. Dopiero poznanie pełnej budowy formy narracyjnej „ułatwia rozumienie i stwarzanie znanych już historii, sprzyja percepcji nowych opowiadań, a także pomaga w tworzeniu zupełnie nowych historii" (Kielar-Turska, 1989, s. 108, 110). Opanowanie umiejętności

2 Arthur Applebee (1978, za: Bokus, 1991, s. 25-26) wyróżnia sześć stadiów rozwoju struktury narracyjnej: wczesne formy prenarracyjne (aktywność językowa dziecka polega na relacjonowaniu tego, co dziecko w danej chwili widzi, co zwraca jego uwagę; nie łączy ono poszczególnych ilustracji, postaci w związki przyczynowo-skutkowe); sekwencje skojarzeniowe (zestawienie zdarzeń pod względem nie chronologicznym czy przyczynowym, ale treściowym, pod wpływem jakiejś wspólnej cechy, która łączy dane przedmioty czy bohaterów); prymitywna narracja (tworzenie opowiadania na podstawie stałego elementu narracji, np. głównego bohatera, zdarzenia; w końcowej części tego typu narracji pojawia się ocena postaci lub zdarzenia); łańcuchy niezogniskowane, rozproszone (przedstawiane zdarzenia powiązane są logicznie lub przyczynowo-skutkowo, ale ciągłość narracji nie jest jeszcze zachowana); łańcuchy zogniskowane (przedstawione zdarzenia łączy postać bohatera w sposób logiczny i przyczynowo-skutkowy; brakuje jednak ukazania celu działania postaci oraz nie ma wyraźnego zakończenia opowiadania lub jest ono niezgodne z wcześniejszą treścią); prawdziwa narracja (zdarzenia zostają połączone w logiczną i spójną całość, przedstawiony jest cel działań bohatera, a zakończenie opowiadania nawiązuje do jego początku). 
tworzenia opowiadania (oraz opisu i dialogu - jako trzech podstawowych from wypowiedzi) stanowi podstawę rozwoju sprawności komunikacyjnych, a także społecznych (Grabias, Kurkowski, Woźniak, 2002, s. 9). Może przełożyć się też na sposób nabywania umiejętności szkolnych (m.in. czytania, pisania) oraz na jakość uczestnictwa w życiu społecznym (Przybyla, 2018, s. 306-316).

Narracja, zdaniem Stanisława Grabiasa, jest najtrudniejszą formą ludzkiej aktywności językowej, świadczy o możliwościach umysłowych człowieka. Odtworzenie wszystkich komponentów wypowiedzi narracyjnej i przedstawienie ich zgodnie z porządkiem czasowym, przyczynowym i przestrzennym „zaświadcza o pełni umysłowych możliwości człowieka" (Grabias, 2015, s. 22). Badania nad mową osób z różnymi zaburzeniami, takimi jak choroba Alzheimera, schizofrenia czy afazja, pokazują, że ich sprawność narracyjna jest w części utracona lub ograniczona albo ulega całkowitej dezintegracji (Grabias, 2015, s. 24).

Tomasz Woźniak w swych badaniach wykazuje, że osoby ze schizofrenią, w zależności od specyfiki zaburzenia $\mathrm{w}$ danym przypadku, w ogóle nie tworzą wypowiedzi narracyjnych lub wypowiedzi te cechuje niespójność, niepełność, zdezintegrowanie. Przedstawiane przez chorych obrazy narracyjne są upraszczane, ubogie pod względem wartości informacyjnej lub dochodzi do niewłaściwego sposobu intepretowania zaprezentowanych zdarzeń (Woźniak, 2005, s. 129, 204). Rozpad spójności odnosi się przede wszystkim do wypowiedzeń złożonych i wiąże się z zaburzeniami: schematu narracyjnego, relacjonowania przebiegu zdarzeń z zachowaniem związków przyczynowo-skutkowych czy relacji czasowych, zauważenia oraz zaprezentowania tematu nadrzędnego. „Pacjenci dostrzegają pojedyncze fakty, ale $\mathrm{z}$ trudnością układają się one $\mathrm{w}$ jakieś sensowne, większe całości. Albo też układają się wedle innych reguł niż te, których uczą nas zachowania społeczne" (Woźniak, 2005, s. 207). Zaburzenia spójności wypowiedzi narracyjnej w schizofrenii uniemożliwiają właściwą interpretację rzeczywistości, wpływając tym samym na jakość życia chorego w społeczeństwie.

Jolanta Panasiuk, na podstawie analizy badań nad realizacją tekstu w afazji, prezentuje model zachowań językowych oraz interakcyjnych, udowadniając, że jednostka w sytuacji utraty kompetencji (językowej, komunikacyjnej, kulturowej) wypracowuje kompensujące strategie komunikacyjne (Panasiuk, 2013, s. 207). W wypadku osób z afazją występują wszystkie typy wypowiedzi: teksty, nie-teksty, a przede wszystkim teksty patologiczne, w których zaburzona jest warstwa substancjalna, spójność gramatyczna oraz semantyczno-pragmatyczna. Realizacje tekstów narracyjnych ograniczają problemy językowe natury leksykalnej, gramatycznej i składniowej. Poza tym badaczka zauważa, że u tych samych chorych występuje różny poziom sprawności w tworzeniu opisu i opowiadania. W rozmowach potocznych zaś realizowana jest specyficzna, swoista struktura dialogu, która przede wszystkim polega na zmianie proporcji aktywności interlokutorów. Osoby z afazją rzadziej przejmują inicjatywę w rozpoczynaniu rozmowy lub ich 
intencje są prowokowane kontekstem sytuacyjnym. Następuje także rozluźnienie tematyczne linii dialogu przez wprowadzanie nowych tematów do rozmowy (Panasiuk, 2013, s. 311).

Według Grażyny Jastrzębowskiej (2003, s. 10) zaburzenia mowy wynikające z trudności realizacyjnych w tworzeniu wypowiedzi słownych przy właściwie rozwiniętych kompetencjach mogą również wpływać na zniekształcenia tekstu. Tak jest chociażby w przypadku jąkania. Zbigniew Tarkowski (1987, s. 10) uważa, że w wypowiedziach osób jąkających się dochodzi do zakłóceń treści oraz spójności konstruowanych przez nie tekstów. Wzrost natężenia objawów niepłynności mówienia zwiększa się w wypowiedziach dialogowych i narracyjnych, zwłaszcza dotyczy to form o skomplikowanej strukturze syntaktycznej (Tarkowski, 2017, s. 124-125). „W przypadku jąkania występują utrudnienia realizacyjne, które przerywają płynność ciągu fonicznego wypowiedzi, co utrudnia rekonstrukcję semantycznego i gramatycznego kształtu wypowiedzi” (Panasiuk, Woźniak, 2001, za: Faściszewska, 2020, s. 105). Do analogicznych wniosków dochodzi Maria Faściszewska (2020), opierając się na autorskich badaniach nad sposobem tworzenia wypowiedzi dialogowych i narracyjnych osób jąkających się: „Nadmiar powtórzeń, nienaturalnych przedłużeń, bloków, embolofrazji utrudnia zbudowanie dobrego tekstu oraz zrozumienie komunikatu. Szczególnie nadmierna liczba embolofrazji w postaci słów przerywników czy przedłużonych dźwięków ma wpływ na niską jakość wypowiedzi” (s. 212). Badaczka zauważa również, że nasilenie objawów niepłynności u kobiet jest większe w wypowiedziach narracyjnych niż w dialogowych. U mężczyzn w przypadku realizacji obu form wypowiedzi pozostaje ono na podobnym poziomie (Faściszewska, 2020, s. 204). Osoby jąkające się mają też trudności z rozbudowaniem opowiadania, tworzą najczęściej krótkie, często jednowyrazowe wypowiedzi, cechujące się zredukowaniem treści semantycznej, a także struktury ${ }^{3}$. „Trudności z tworzeniem dłuższych wypowiedzi mogą być spowodowane nasiloną logofobią, zaburzeniami płynnego wypowiadania się, nasilonym blokowaniem, ale również niskimi sprawnościami i kompetencjami językowymi” (Faściszewska, 2020, s. 141).

Trudności w opanowaniu podsystemów języka na płaszczyźnie zarówno mówionej, jak i pisanej napotykają też dzieci dwujęzyczne czy wielojęzyczne. Jeśli u dziecka uczącego się więcej niż jednego kodu językowego wystąpią nawet niewielkie zakłócenia rozwojowe, jak skrzyżowana lateralizacja czy zaburzenia słuchu fonemowego, to nabywanie kompetencji językowej może zostać zahamowane (Cieszyńska, 2013, s. 166). Wówczas rozwój sprawności narracyjnej również przebiega $\mathrm{z}$ opóźnieniem lub w stopniu niewystarczającym do budowania po-

${ }^{3}$ Choć w strukturze wypowiedzi osób jąkających się występowała formuła inicjalna, to finalna często była ograniczana do użycia elementu terminalnego typu: no to tyle, koniec (Faściszewska, 2020, s. 119). 
prawnych wypowiedzi pod względem gramatycznym, semantycznym czy leksykalnym. Marzena Błasiak-Tytuła (2015) na podstawie swych badań stwierdza, że dzieci bilingwalne cechuje znacznie obniżony poziom umiejętności tworzenia tekstów narracyjnych (opowiadania i opisu). W ich wypowiedziach, zbudowanych najczęściej z pojedynczych wyrazów, zlepków wyrazowych lub prostych zdań, zauważa się liczne błędy fleksyjne i składniowe. Opisywane zdarzenia są przedstawiane bez zachowania logicznej spójności czy ciągu przyczynowo-skutkowego (Błasiak-Tytuła, 2015, s. 140-143).

Rodzice dzieci dwujęzycznych sądzą, że „przesunięcie czasowe w opanowaniu umiejętności fleksyjnych i syntaktycznych w języku etnicznym w stosunku do języka kraju osiedlenia jest naturalnym zjawiskiem" (Błasiak-Tytuła, 2015, s. 171). Taki sposób myślenia jest nieprawidłowy, gdyż w celu zapewnienia właściwego rozwoju sprawności językowych i komunikacyjnych dziecka bilingwalnego należy zapewnić mu dostęp do odpowiednich pod względem ilości i jakości bodźców językowych w obydwu nabywanych językach (Orłowska-Popek, Błasiak-Tytuła, 2017, s. 158-159). Bo „nie chodzi tylko o przełączanie kodów i używanie słów nieznanych w języku etnicznym, ale o przyjmowanie perspektyw: czasowej, społecznej, kulturowej" (Cieszyńska, 2013, s. 173). Należy zadbać o to, by ograniczenia w opanowywaniu kompetencji językowej nie wpłynęły na rozwój intelektualny, emocjonalny i społeczny młodego człowieka. Jak pokazują badania Jagody Cieszyńskiej, dzieci polskich emigrantów, które oddano w 18. miesiącu życia do żłobka, w 12. roku życia nadal nie posiadały w pełni ukształtowanego systemu językowego w żadnym z języków (Cieszyńska, 2013, s. 175).

Doświadczenia logopedyczne wskazują, że rozwój sprawności narracyjnej przebiega według określonych schematów, co jednak nie zawsze jest możliwe. Sprawność narracyjna często „staje się niedostępna osobom niesłyszącym, dzieciom z autyzmem, osobom obarczonym upośledzeniem umysłowym" (Grabias, 2015, s. 24).

Osoby niedosłyszące lub niesłyszące mają ograniczoną możliwość naturalnego rozwoju i przyswojenia systemu językowego. To w konsekwencji prowadzi do pojawienia się trudności w sferze kompetencji językowej oraz komunikacyjnej, utrudniając tym samym interakcje społeczne w szerszym kręgu odbiorców (nie tylko osób z uszkodzonym słuchem). Język pełni podstawową i najważniejszą funkcję $\mathrm{w}$ interakcji. Chociaż istnieją alternatywne metody komunikacji, jak np. piktogramy, fonogesty, język migowy, to jednak mowa umożliwia znacznie szersze uczestnictwo w życiu społecznym. Zachowania niejęzykowe przyporządkowują człowieka do konkretnej grupy (Grabias, 2019, s. 217). „Doświadczenie pedagogiczne dobitnie wykazało, że warunkiem biegłego opanowania języka w piśmie jest opanowanie jego podstaw w bezpośrednim komunikowaniu się: czyli w mowie" (Krakowiak, 2012, s. 223). Osoby z wadą słuchu opanowują umiejętność pisania w sytuacji ograniczonej praktyki językowej, czyli zdaniem Dryżałowskiej - równo- 
legle z przyswajaniem języka. Stąd według badaczki tak wiele nieprawidłowości językowych, „dziwacznych sformułowań, uproszczeń konstrukcji gramatycznych" w pracach pisemnych osób z uszkodzonym słuchem (Dryżałowska, 2007, s. 68). Dlatego zasadne wydaje się stwierdzenie, że powinny one uczyć się języka zarówno w postaci pisanej, jak i mówionej przez aktywne uczestnictwo w życiu społeczności słyszących - w świecie dźwięków.

\section{Metodologia badań własnych}

Celem badań było sprawdzenie, jakie trudności sprawia osobom z wadą słuchu tworzenie tekstu narracyjnego (opowiadania) na podstawie pięcioelementowej historyjki obrazkowej, w formie pisanej. A przede wszystkim - czy w umysłach osób z uszkodzonym słuchem istnieje struktura opowiadania. W jaki sposób przedstawiają $\mathrm{w}$ tej formie narracji wycinek $\mathrm{z}$ rzeczywistości po uwzględnieniu wątku przyczynowo-skutkowego i aspektu czasowego.

W badaniu wzięła udział grupa piętnaściorga studentów Uniwersytetu Przyrodniczo-Humanistycznego w Siedlcach uczęszczających na lektorat języka polskiego dla osób z uszkodzonym słuchem - sześć kobiet i dziewięciu mężczyzn (tabela 1). Cztery osoby w ogóle nie posługiwały się językiem migowym, tylko komunikowały się werbalnie (posiadały implant ślimakowy, który został im wszczepiony w różnych okresach życia. Pozostali studenci używali języka migowego jako podstawowego środka komunikacji oraz mowy (dodatkowo czytali $\mathrm{z}$ ruchu warg). Na podstawie własnych obserwacji podczas zajęć oraz po zapoznaniu się $\mathrm{z}$ wypowiedziami werbalnymi i pisemnymi studentów mogę stwierdzić, że grupa charakteryzowała się bardzo zróżnicowanym poziomem kompetencji językowej. Co ciekawe, nie zawsze sprawność językowa była uwarunkowana lepszą percepcją słuchową.

TABELA 1. Ogólna charakterystyka grupy badawczej

\begin{tabular}{|c|c|c|}
\hline 1. LiczBA osóв & \multicolumn{2}{|c|}{15} \\
\hline 2. PŁé́ & 6 kobiet & 9 mężczyzn \\
\hline 3. WIEK W CZASIE BADANIA & & \\
\hline - 20 lat & 2 & 1 \\
\hline - 21 lat & 1 & 2 \\
\hline - 22 lata & - & 1 \\
\hline | 23 lata & 1 & 1 \\
\hline - 24 lata & 2 & 4 \\
\hline
\end{tabular}


cd. tabeli 1

\begin{tabular}{|c|c|c|}
\hline $\begin{array}{l}\text { 4. RoDZAJ USZKODZENIA NARZĄDU SŁUCHU } \\
\text { " lekki } \\
\text { " umiarkowany } \\
\text { " znaczny } \\
\text { " głęboki }\end{array}$ & $\begin{array}{l}1 \\
3 \\
- \\
2\end{array}$ & $\begin{array}{l}1 \\
3 \\
1 \\
4\end{array}$ \\
\hline $\begin{array}{l}\text { 5. CZAS USZKODZENIA SŁUCHU } \\
\text { " prelingwalny } \\
\text { " perilingwalny } \\
\text { " postlingwalny }\end{array}$ & $\begin{array}{l}6 \\
- \\
-\end{array}$ & $\begin{array}{l}6 \\
2 \\
1\end{array}$ \\
\hline $\begin{array}{l}\text { 6. RodzAJ SzKOŁY } \\
\text { " szkoła masowa } \\
\text { " szkoła dla osób niesłyszących } \\
\text { " na początku szkoła masowa, potem szkoła } \\
\text { dla osób niesłyszących (liceum, technikum) }\end{array}$ & $\begin{array}{l}5 \\
1 \\
-\end{array}$ & $\begin{array}{l}4 \\
4 \\
1\end{array}$ \\
\hline $\begin{array}{l}\text { 7. Sposób APARATOWANia } \\
\text { " aparat słuchowy } \\
\text { " implant ślimakowy }\end{array}$ & $\begin{array}{c}2 \\
4 \\
\text { (od 8. r.ż.; } \\
\text { od 10. r.ż.; od 20. r.ż.) }\end{array}$ & $\begin{array}{c}7 \\
2 \\
\text { (od 15. r.ż.; od 4. r.ż.) }\end{array}$ \\
\hline $\begin{array}{l}\text { 8. PREFERENCJA SPOSOBU KOMUNIKACJI } \\
\text { " mowa (foniczna) } \\
\text { " język migowy + odczytywanie z ruchu warg } \\
\text { " mowa + język migowy }\end{array}$ & $\begin{array}{l}5 \\
1 \\
-\end{array}$ & $\begin{array}{l}3 \\
6 \\
-\end{array}$ \\
\hline $\begin{array}{l}\text { 9. WYSTĘPOWANIE NIEDOSŁUCHU W RODZINIE } \\
\text { " tylko osoba badana } \\
\text { " osoba badana i rodzice } \\
\text { " osoba badana i rodzeństwo }\end{array}$ & $\begin{array}{l}2 \\
- \\
4\end{array}$ & $\begin{array}{l}7 \\
- \\
2\end{array}$ \\
\hline
\end{tabular}

ŹróDŁo: Opracowanie własne.

Zbieranie wypowiedzi pisemnych było prowadzone indywidualnie lub w grupie dwuosobowej. W przypadku osób posługujących się tylko językiem migowym badanie odbywało się w obecności biegłej tłumaczki języka migowego Haliny Grzeszczuk. W pierwszej części badania zaprezentowano studentom pięcioelementową historyjkę obrazkową ${ }^{4} \mathrm{z}$ prośbą o dokładne przyjrzenie się tworzącym ją ilustracjom. Następnie zostali oni poproszeni o ułożenie obrazków we właściwej kolejności (odzwierciedlającej, co się wydarzyło najpierw, potem i na końcu).

${ }^{4}$ Wykorzystano pięcioelementową historyjkę obrazkową z serii „Co się stanie? Historyjki obrazkowe” (wydawnictwo Schubi). Starano się wybrać historyjkę, która nie będzie zbyt infantylna dla studentów, a zarazem będzie ciekawa, nietypowa. Taką, w której oprócz zauważenia relacji przyczynowo-skutkowych będzie można odnieść się też do emocji i oceny zachowania bohaterów. 
W drugiej części badania studenci mieli samodzielnie stworzyć wypowiedź narracyjną (opowiadanie) o tym, co się wydarzyło w zaprezentowanej historyjce. Zwrócono też uwagę, że wypowiedź powinna mieć formę opowiadania ujętego w odpowiednią strukturę: wstęp, rozwinięcie i zakończenie. Przed rozpoczęciem zadania jeszcze raz podkreślono, że ma to być przedstawienie tego, co przytrafiło się chłopcu z ilustracji, a nie opisywanie poszczególnych obrazków. Tak rozbudowana instrukcja wydawała się zasadna, ponieważ wielu badaczy (Kołodziejczyk, 2015; Krakowiak, 2012; Rakowska, 1992) wskazuje, że osoby z uszkodzonym słuchem posiadają trudności w tworzeniu wypowiedzi narracyjnych.

Superstrukturę opowiadania analizowano na podstawie modelu zaproponowanego przez Stanisława Grabiasa (2015, s. 22-23), który wyróżnił:

- inicjację - zastosowanie formuły rozpoczynającej opowiadanie;

- ekspozycję - wypowiedzi prezentujące sytuację;

- komplikację - przedstawienie kulminacyjnego zdarzenia opowiadania;

- rozwiązanie - sposób wyjścia z komplikacji;

- kodę - użycie formuły kończącej opowiadanie.

Zadanie z pierwszej części badania zostało wykonane prawidłowo przez prawie wszystkich. Studenci bez większych trudności właściwie uporządkowali poszczególne elementy historyjki obrazkowej, zachowując ciąg zarówno czasowy, jak i przyczynowo-skutkowy. Jedna osoba w nieprawidłowej kolejności ułożyła obrazki, zmieniając zakończenie. Ostatni obrazek historyjki potraktowała jako pierwszy, co spowodowało zmianę sekwencji prezentowanych zdarzeń i założonej treści opowiadania.

Przystępując do drugiej części badania, kilka osób (pięć) poprosiło o podanie nazwy rzeczy, wskazując ją bezpośrednio na ilustracji i używając omówienia, np.: to coś, co jest [o]puszczane, jak jedzie pociąg. Żadna z osób badanych nie zachowała właściwego zapisu graficznego tekstu, nie dokonała jego rozczłonkowania na trzy konstytutywne elementy: wstęp, rozwinięcie, zakończenie. Trzy osoby ponumerowały poszczególne obrazki i zgodnie z tym wypunktowały treść swoich wypowiedzi, opisując każdą ilustrację, bez zastosowania leksemów łączących przebieg wydarzeń w spójną całość, np.: (a) 1. Chłopiec i dziewczynka jechali na rowerem do szkoły, droga przez tora a zapora zamknęła w czasie jeździ pociagiem. 2. Chłopiec z niebieskie kurtkę nie chciał czekać z rowera tylko zostawił oparcie za pomoca zapora. I przyszedł drugi kolega, pokazał swoje umiejętności z rowerem; (b) 3. Ostatni kolegi zwolnić szlaban i rower podniesieć szlabanem. 4. Został pod drzewem bo rower wisi szlabanem. 5. Przyjechał najpóźniej do szkoły.

Jedna osoba treść całego opowiadania zapisała w formie jednego rozbudowanego zdania złożonego współrzędnie w połączeniu ze zdaniem podrzędnym,

${ }^{5}$ W cytowanych przykładach wypowiedzi osób badanych zachowuję oryginalną pisownię oraz zapis, nie zmieniając nieprawidłowości językowych, stylistycznych czy interpunkcyjnych. 
nie stosując przy tym żadnych znaków interpunkcyjnych. Funkcję rozdzielenia poszczególnych części składowych tego wypowiedzenia przejęły frekwencyjnie spójniki łączne $(i, a)$ oraz przeciwstawny (ale):

Pewnego dnia chłopca $w$ niebieskim kurtce jezdzit rowerem $z$ koledzy $i$ tam był zabora pociagiem który zamkną i ten chtopiec zostawit rowerem przy zaborze i gadał z kolegami a jak pociag już odjechała i zabora zaczyna otwierać ale z rowyzonym rowerem do góry a koledzy musieli zostawić kolegi w niebieskim kurtce ponieważ nie moga spóźnić na lekcja a tam niebieskim kurtce musiat poczekać aż zabora będzie zamknięta i zabrać rowera i py[nieczytelne] do szkoty ale nie stety spóźnit na lekcji.

Ten przykład budowy składniowej opowiadania pozwala zauważyć pewną zależność tworzenia tego typu tekstów przez osoby z wadą słuchu. Polega ona na zrelacjonowaniu zauważonych elementów rzeczywistości bez spójnego i płynnego przejścia między poszczególnymi zdarzeniami.

Pięć osób badanych zastosowało formułę rozpoczynającą opowiadanie, którą najczęściej było - pewnego dnia (trzy osoby), zaś dwie osoby użyły bardziej rozbudowanego wprowadzenia - Był piękny, słoneczny dzień...; pewnego, słonecznego dnia. Pozostali studenci rozpoczęli wypowiedzi od ekspozycji (sześć osób), nakreślając ogólną treść całej zaistniałej sytuacji bez osadzenia jej w czasie, np.: Chłopiec jechał ze swoja koleżanka na rowerach do szkoły; Chłopiec z niebieskimi kurtka z znajomi jechali rowerem do szkoły; Chłopiec wraz koleżanka wybrał się na przejażdżkę rowerowa do szkoły... Siedem osób w części wstępnej opowiadania przeszło do bezpośredniego relacjonowania zdarzeń, np.: Dzieci podjeżdżaja pod bocznice kolejowej; Dwójka przyjaciół stoja przed przejazdem; Pewnego dnia chłopiec i dziewczynka zatrzymuja się przy szlabanie; Kolego jeździli rowerami przed kolegem i zatrzymali się.

TABELA 2. Elementy struktury opowiadania w pracach pisemnych osób z wadą słuchu

\begin{tabular}{|c|c|c|c|c|}
\hline \multirow[t]{2}{*}{$\begin{array}{c}\text { Elementy struktury } \\
\text { opowiadania }\end{array}$} & \multicolumn{2}{|c|}{$\begin{array}{c}\text { Osoby badane, } \\
\text { które wbudowały dany komponent } \\
\text { w strukturę wypowiedzi }\end{array}$} & \multicolumn{2}{|c|}{$\begin{array}{l}\text { Osoby badane, } \\
\text { które nie wbudowały } \\
\text { danego komponentu } \\
\text { w strukturę wypowiedzi }\end{array}$} \\
\hline & [os. / 15 os.] & [\%] & [os. / 15 os.] & [\%] \\
\hline Inicjacja & 5 & 33 & 10 & 67 \\
\hline Ekspozycja & 6 & 40 & 9 & 60 \\
\hline Komplikacja & 13 & 87 & 2 & 13 \\
\hline Rozwiązanie akcji & 12 & 80 & 3 & 20 \\
\hline Koda (zakończenie) & 2 & 13 & 13 & 87 \\
\hline
\end{tabular}

ŹróDŁo: Opracowanie własne. 
Studenci zauważyli kulminacyjne zdarzenie (trzynaście osób), które znacząco wpłynęło na przebieg opisywanej historii. Jednak sposób jego ujęcia i zaprezentowania był zróżnicowany. W niektórych pracach momentu kulminacyjnego dotyczyło jedno rozbudowane zdanie, czasem zaś - dwa zdania, a nawet więcej (trzy, cztery). Analizując teksty pisemne studentów z niepełnosprawnością słuchową, można zauważyć, że opisanie komplikacji stanowiło centralną część całego opowiadania pod względem zarówno treściowym, jak i syntaktycznym. W wypadku 75\% pozyskanych tekstów przedstawienie tego momentu zajęło objętościowo niemalże całe opowiadanie. Na przykład: Kiedy pociag przejechał jeden $z$ chłopców, który opart rower o szlaban nie pomyślał ze szlaban po przejechaniu pociagu może się podnieść się wraz z jego rowerem; Czekając, chłopiec postawił swój pojazd przy szlabanie i spotkat innego znajomego z klasy, który też spieszył się na lekcje. Nagle szlaban się podniósł, i razem $z$ nim... rower chłopca; [...] chłopiec $z$ niebieskim kurtka zostawit na zaporem, rozmawiał z znajomi, czekał aż zapór otwiera. [...] Pociag już jechał, a zapór otwierat. Zapór wisat rower; Czekajac pozostawit rower przy zaporze, przyjechał kolega. Koleżanka zauważyła jak zapora podniosła się wraz z rowerem; Chłopiec został rampy, a resztę trzymali rowera. Rozmawiali. Ona krzyczała go, że patrzyć nagle rampa otwierała wysiać rowera do góry.

Rozwiązanie akcji, kolejny element superstruktury opowiadania, został zawarty w dwunastu pracach pisemnych osób biorących udział w badaniu. Oba komponenty opowiadania: komplikacja i rozwiązanie były ujęte w większości prac pisemnych osób $\mathrm{z}$ wadą słuchu i opierały się na konkretnym zrelacjonowaniu zauważonych faktów. Zachowana chronologia zdarzeń spowodowała, że teksty wydały się tematycznie spójne. Jednak w większości opowiadań zauważono tendencję do opisywania poszczególnych ilustracji bez traktowania ich globalnie jako elementów złożonej całości. $\mathrm{Z}$ tego może też powodu w pracach było niewiele operatorów międzyzdaniowych, które określałyby stosunki czasowe (w wypadku czterech prac wynotować można następujące określenia: po chwili, potem, nagle) czy przyczynowo-skutkowe. Poza tym w rekonstrukcji przedstawianych zdarzeń zauważono mieszanie czasów: teraźniejszego z przeszłym (w dwunastu pracach), np.: Chłopiec nie zdąży go zabrać. Gdy brama nie została zamknięta rower nadal jest na górze. Chłopiec czeka aż zamkna bramę żeby mógł zabrać rower; Chłopiec $z$ zielona kurtkę i dziewczynka pojechali, a drugi chłopiec leży i czeka aż pociag przyjedzie wtedy opuści zaporami. W końcu chłopiec dotart do szkoły, opowiada nauczyciel o swoja sytuacje przez tego spóźnit; Oni pojeździli do szkoły a on leżał przy drzewa i czekał. Już po dołu rampy wzią tego i jeździł do szkoly; Po przejeździe szlaban podnosi się do góry na którym opiera się rower. Dzieci pojechały do szkoły, a chłopiec musi czekać na następny pociag, aby odebrać rower $z$ szlabanu.

Prawie wszyscy studenci (trzynaścioro) nie użyli formuły kończącej opowiadanie ani też nie wydzielili zakończenia graficznie (jako odrębnego akapitu). Tylko jedna osoba ujęła kodę w postaci zwrotu - koniec, druga zaś zakończenie zapisała 
w formie podsumowania, które odnosiło się do stanu emocjonalnego głównego bohatera: Podsumowując, ten dzień byt jednym z gorszych okresów w życiu chłopca, gdyż ta sytuacja został wyśmiany przez swoich rówieśników i przez spóźnienie się dostał uwage od nauczyciela.

\section{Wnioski}

Na podstawie zebranego materiału można stwierdzić, że dla osób z uszkodzonym słuchem ułożenie historyjki obrazkowej zgodnie z następstwem czasowym i przyczynowo-skutkowym było zadaniem łatwym, które wykonali bez większego wysiłku. Trudność pojawiła się w zbudowaniu płynnego, spójnego tekstu pisemnego osadzonego na pełnej, hierarchicznej superstrukturze opowiadania. Najczęściej pomijanym elementem kompozycyjnym opowiadania były inicjacja oraz koda. Osoby z niepełnosprawnością słuchową zawierały w swych narracjach wydarzenie kulminacyjne oraz właściwie przedstawiały rozwiązanie akcji. Można stwierdzić, że dostrzegały ciąg wzajemnie powiązanych zdarzeń, ale nie potrafiły ich połączyć w spójną, logiczną całość. Nałożyły się na to liczne błędy fleksyjne oraz składniowe, które utrudniały płynne połączenie elementów przedstawionej rzeczywistości. Znaczna część opowiadań studentów z niepełnosprawnością słuchową miała cechy języka potocznego oraz skrótu myślowego, co powodowało, że narrator relacjonował tylko najważniejsze elementy zdarzenia, nie wprowadzając w jego treść opisów miejsca akcji czy wyglądu bohaterów. Frekwencyjnie niewiele też odnotowano leksemów, wyrażeń określających stosunki czasowe lub dotyczących sposobu, w jaki były wykonywane zaprezentowane w historyjce czynności. $\mathrm{W}$ tekstach pisanych studentów $\mathrm{z}$ wadą słuchu przeważały zdania pojedyncze, pojedyncze rozbudowane oraz złożone współrzędnie (parataktycznie). Niewiele było opowiadań, które zawierały w swej budowie składniowej konstrukcje podrzędne (hipotaktyczne). Może ma to potwierdzenie w artykule Aldony Skudrzyk i Jacka Warchali (2010), w którym autorzy stwierdzają, że przewaga parataksy nad hipotaksą w pracach pisemnych młodzieży szkolnej świadczy o sposobie konceptualizacji świata opartym na myśleniu konkretnym, blokującym kształtowanie się myślenia abstrakcyjnego oraz skłaniającego do refleksji i interpretacji.

Hipotaksa [...] nakłada na świat siatkę relacji przestrzenno-czasowych, pokazuje elementy świata we wzajemnych związkach i relacjach; parataksa natomiast ujawnia myślenie w kategoriach współistnienia równorzędnych elementów i stanów rzeczy ułożonych (pomyślanych) linearnie. [...] Parataksa jest rodzajem skanowania świata, podczas gdy hipotaksa interpretuje świat (Skudrzyk, Warchala, 2010, s. 64). 


\section{Podsumowanie}

$\mathrm{W}$ świetle przedstawionych wyników badań zasadne wydaje się założenie, że w kształceniu integracyjnym osób z niepełnosprawnością słuchową, jak także w programowaniu terapii logopedycznej, należy uwzględnić ćwiczenia z zakresu kształtowania sprawności budowania opowiadań. Oprócz prowadzenia ćwiczeń: frazeologiczno-słownikowych, ukierunkowanych na wzbogacanie zasobu słownictwa, fleksyjnych, syntaktycznych (zwłaszcza w zakresie budowania zdań pojedynczych rozwiniętych, złożonych współrzędnie, a przede wszystkim podrzędnie), ważne wydaje się pogłębianie i rozwijanie wiedzy o opowiadaniu i jego pełnej, hierarchicznej strukturze (Przybyla, 2018, s. 221-222). Ma to uzasadnienie w wynikach badań prowadzonych przez zespół pod kierunkiem Marii Kielar-Turskiej (2018, s. 221-222), które wykazały, że dzieci dysponujące lepszą reprezentacją poznawczą na poziomie ukrytym, uświadamiały sobie cechy wypowiedzi narracyjnej i potrafiły tę wiedzę zwerbalizować. To skutkowało też wyższym poziomem jawnym poznawczej reprezentacji narracji, a tym samym tworzeniem przez nie tekstów dłuższych, z wyraźnie zaznaczoną sekwencją zdarzeń i kompletną, prawidłowo zorganizowaną strukturą.

Opanowanie umiejętności budowania opowiadania świadczy o poziomie kompetencji językowej i komunikacyjnej. Pozwala jednostce w pełni uczestniczyć w życiu społecznym. Poza tym, jak podaje Kielar-Turska (2018, s. 221), ta forma narracji wzbudza wiele emocji, uaktywnia myślenie, a przede wszystkim dostarcza człowiekowi wiedzy o świecie oraz pokazuje, co jest ważne. Pozwala też na kształtowanie myślenia abstrakcyjnego, gdyż rozwija wyobraźnię, skłania do refleksji oraz wyciągania wniosków. Dlatego zadaniem koniecznym wydaje się wyposażenie osób $\mathrm{z}$ wadą słuchu $\mathrm{w}$ sprawność wypowiadania się $\mathrm{w}$ formie opowiadania.

\section{Bibliografia}

Bokus, B. (1991). Tworzenie opowiadań przez dzieci. O linii i polu narracji. Kielce: Energeia.

BŁasıak-TytuŁa, M. (2015). Narracja a rozumienie u dzieci dwujęzycznych. W: M. BŁasıak-TytuŁa, M. Korendo, A. Siudak (red.), Nowa Logopedia. Rozumienie - diagnoza i terapia (t. 6, s. 135-145). Kraków: Wydawnictwo Collegium Columbinum.

CieszyńsKa, J. (2013). Metoda Krakowska wobec zaburzeń rozwoju dzieci. Z perspektywy fenomenologii, neurobiologii i językoznawstwa. Kraków: Wydawnictwo Centrum Metody Krakowskiej.

Dereń, E. (2005). Opis a opowiadanie: typowe słownictwo szkolnych form wypowiedzi. Nauczyciel i Szkoła, 3-4(28-29), 145-159. 
E. DzıĘCıOŁ-ChLıвıuk: Superstruktura opowiadania na podstawie wypowiedzi osób...

DryżAŁowska, G. (2007). Rozwój językowy dziecka z uszkodzonym stuchem a integracja edukacyjna. Model kształcenia integracyjnego. Warszawa: Wydawnictwa Uniwersytetu Warszawskiego.

DziĘCiOŁ-CHLibiuk, E. (2019). Realizacja struktury opisu na podstawie wypowiedzi ustnych i pisanych osób z uszkodzonym słuchem. Logopedia Silesiana, 8, 209-232.

Faściszewska, M. (2020). Jąkanie. Wypowiedzi dialogowe i narracyjne osób jąkających się. Gdańsk: Wydawnictwo Uniwersytetu Gdańskiego.

Grabias, S., (2012). Teoria zaburzeń mowy. Perspektywy badań, typologie zaburzeń, procedury postępowania logopedycznego. W: S. Grabias, Z.M. KuRKowski (red.), Logopedia. Teoria zaburzeń mowy (s. 15-71). Lublin: Wydawnictwo Uniwersytetu Marii Curie-Skłodowskiej.

Grabias, S. (2015). Postępowanie logopedyczne. Standardy terapii. W: S. Grabias, J. Panasiuk, T. WoźNiak (red.), Logopedia. Standardy postępowania logopedycznego (s. 13-35). Lublin: Wydawnictwo Uniwersytetu Marii Curie-Skłodowskiej.

Grabias, S. (2019). Jezzyk wachowaniach społecznych. Podstawy socjolingwistyki i logopedii. Lublin: Wydawnictwo Uniwersytetu Marii Curie-Skłodowskiej.

Grabias, S., Kurkowski, Z.M., WoźNiak, T. (2002). Logopedyczny test przesiewowy dla dzieci w wieku szkolnym. Lublin: Wydawnictwo Uniwersytetu Marii Curie-Skłodowskiej, Zakład Logopedii i Językoznawstwa Stosowanego, Polskie Towarzystwo Logopedyczne.

Jastrzębowska, G. (2003). Wprowadzenie. Problemy terminologiczne i definicyjne. W: T. GaŁKowski, G. Jastrz̨̨вowska (red.), Logopedia - pytania i odpowiedzi. Podręcznik akademicki (t. 2, s. 9-36). Opole: Wydawnictwo Uniwersytetu Opolskiego.

Jóźwicki, T. (1984). Opowiadanie jako forma wypowiedzi w klasach początkowych. Warszawa: Wydawnictwa Szkolne i Pedagogiczne.

Kielar-Turska, M. (1989). Mowa dziecka. Słowo i tekst. Kraków: Wydawnictwo Uniwersytetu Jagiellońskiego.

Kielar-Turska, M. (2018). Dziecięca kompetencja narracyjna: rozumienie istoty narracji i umiejętność opowiadania. Studia Pragmalingwistyczne, 10, 211-224.

KoŁodZIEJCZyк, R. (2015). Trudności gramatyczne u dzieci i młodzieży z uszkodzeniami słuchu. W: E. Muzy ka-Furtak (red.), Surdologopedia. Teoria i praktyka (s. 156-175). Gdańsk: Harmonia Universalis.

Krakowiak, K. (2012). Dar języka. Podręcznik metodyki wychowania językowego dzieci i młodzieży z uszkodzeniami narządu stuchu. Lublin: Wydawnictwo Katolickiego Uniwersytetu Lubelskiego.

KulawiK, A. (1997). Poetyka. Wstęp do teorii dzieła literackiego. Kraków: Antykwa.

Kulpa, J., WięcKowski, R. (1997). Formy ćwiczeń w mówieniu i pisaniu. W: M. WĘGlińsKa (red.), Opowiadanie jako forma wypowiedzi w klasach początkowych (s. 62-64). Kraków: Impuls.

Kyrc, B. (2018). Rozwijanie kompetencji narracyjnej dziecka dwujęzycznego w Polsce a jego sukces edukacyjny. Porównawcze studium przypadku. Języki Obce w Szkole, 4, 85-92.

Malendowicz, J. (1997). Kształtowanie pisemnych wypowiedzi uczniów w klasach II-IV. W: M. WĘGLIŃsKa (red.), Opowiadanie jako forma wypowiedzi w klasach początkowych (s. 59-62). Kraków: Impuls.

NaGajowa, M. (1977). Ćwiczenia w mówieniu i pisaniu w klasach V-VIII szkoły podstawowej. Warszawa: Wydawnictwa Szkolne i Pedagogiczne.

Nagajowa, M. (1990). ABC metodyki języka polskiego dla początkujących nauczycieli. Warszawa: Wydawnictwa Szkolne i Pedagogiczne.

OrŁowska-Popek, Z., BŁasiak-TytuŁa, M. (2017). Dziennik wydarzeń jako technika kształtowania kompetencji komunikacyjnej w sytuacji dwujęzyczności. Conversatoria Linguistica, 11, 157-170.

PANASIUK, J. (2013). Afazja a interakcja. TEKST - metaTEKST - konTEKST. Lublin: Wydawnictwo Uniwersytetu Marii Curie-Skłodowskiej. 
Przybyla, O. (2018). Kompetencja narracyjna uczniów z zaburzeniami rozwoju koordynacji. Logopedia, 47-2, 303-316.

Rakowska, A. (1992). Rozwój systemu gramatycznego u dzieci głuchych. Kraków: Wydawnictwo Naukowe Wyższej Szkoły Pedagogicznej.

SkudrzyK, A., Warchala, J. (2010). Kultura piśmienności młodzieży szkolnej - badania w perspektywie analfabetyzmu funkcjonalnego. Studia Pragmalingwistyczne, 2, 55-65.

Soroko, E., Wojciechowska, J. (2015). Kompetencja narracyjna jako obszar nauczania i oceny edukacji. Studia Edukacyjne, 37, 211-236.

TAR Kowski, Z. (1987). Jąkanie. Zagadnienia etiologii, diagnozy, terapii i prognozy. Warszawa: Wydawnictwo ZSL.

Tarkowski, Z. (2017). Jąkanie. W: Z. Tarkowski (red.), Patologia mowy (s. 123-148). Gdańsk: Harmonia Universalis.

WęGLIŃsKa, M. (1997). Opowiadanie jako forma wypowiedzi w klasach początkowych - istota, struktura. W: M. WĘGLIŃsKa (red.), Opowiadanie jako forma wypowiedzi w klasach początkowych (s. 9-18). Kraków: Impuls.

Witosz, B. (1997). Opis w prozie narracyjnej na tle innych odmian deskrypcji. Zagadnienia struktury tekstu. Katowice: Wydawnictwo Uniwersytetu Śląskiego.

WolAŃsKa, E. (2010). Wykładniki spójności tekstów renarracji tworzonych przez młodzież szkolną w wieku 12-13 lat. Studia Pragmalingwistyczne, 2, 104-114.

Woźniak, T. (2005). Narracja w schiozofrenii. Lublin: Wydawnictwo Uniwersytetu Marii Curie-Skłodowskiej.

Wyrwas, K. (2014). Opowiadania potoczne w świetle genologii lingwistycznej. Katowice: Wydawnictwo Uniwersytetu Śląskiego. 